https://doi.org/10.11646/zoosymposia.17.1.8

http://zoobank.org/urn:lsid:zoobank.org:pub:89855EF1-132E-4E1F-83FE-FFFAC711E244

\title{
The aquatic oligochaete fauna of Lake Çıldır, Ardahan-Kars, Turkey, including an updated checklist of freshwater annelids known to occur in the country
}

\author{
NAIME ARSLAN ${ }^{1 *} \&$ DENIZ MERCAN ${ }^{1}$ \\ ${ }^{1}$ Eskişehir Osmangazi University, Science and Art Faculty, Biology Department, Meşelik, 26480, Eskişehir, Turkey. \\ *Corresponding author e-mail: oligo2009@gmail.com
}

\begin{abstract}
In this paper, we present the results of the first survey for aquatic oligochaetes in Lake Çıldır, northeastern Turkey, during which 22 oligochaete species were recorded from the lake. The results of this survey were integrated into an updated and annotated list of oligochaetes and other aquatic annelids occurring in the country, summarized from historical and recent publications. Currently, the freshwater annelid fauna of Turkey includes 150 species of oligochaetes (1 Crassiclitellata, 21 Enchytraeidae, 1 Propappidae, 1 Haplotaxidae, 4 Lumbriculidae, 56 Naidinae, 64 Tubificinae, 2 Lumbricidae), 1 species of Branchiobdellida, and 6 species of Aphanoneura (1 Potamodrilidae and 5 Aeolosomatidae). Although studies focusing on the aquatic oligochaete fauna of Turkey have increased over the past 15-20 years, species diversity still remains unclear.
\end{abstract}

Keywords: Checklist, Annelida, Oligochaeta, oligochaetes, Turkey, Lake Çıldır

\section{Introduction}

Three distinct biogeographical areas are present in Turkey: Anatolian, Mediterranean, the Black Sea regions, and their transition zones. The diverse climatic and geographical features often vary greatly-even within short distances-due to their location in the country (https://www.iucn.org/content/biodiversity-turkey). Surrounded by three seas, Turkey $(783,356 \mathrm{~km} 2$ in area) is uniquely positioned geographically with its mountain ranges such that terrestrial, fresh water, and marine biodiversity is considerably high. The biological diversity of the country can be compared to that of a small continent. Its territory includes forests, mountains, steppes, wetlands, coastal and marine ecosystems as well as different forms and combinations of these systems, supporting considerable species diversity. The faunal biodiversity of Turkey is quite high compared to that of other countries in the temperate zone. Despite the lack of extensive data, invertebrates constitute the largest group among the identified living species. The total number of invertebrate species in Turkey is estimated to be $\sim 19,000$; of these, $\sim 4,000$ species / subspecies are considered to be endemic (International Union for Conservation of Nature 2018). In addition, Turkey is blessed with a diversity of lentic and lotic resources, including 107 major rivers and 25 river basins, more than 120 natural lakes, and 135 wetlands of international significance. The map of Earth's freshwater ecosystems, as published by The Nature Conservancy (2015), is based on the data regarding the distribution and composition of freshwater fish species. According to data presented therein, Turkey has eight different freshwater ecoregions, but as previously stated, these regions are categorized based on their fish, amphibian and reptile species. Therefore in this study, the inland water categorization published by Timm (1980) was used for freshwater oligochaete species. Inland waters have been categorized into six different zoogeographical regions; Turkey is located entirely within the Holoarctic region. Timm (1980) divided the Holoarctic region into six subregions on the basis of the distribution of oligochaetes: Euro-Siberian, West Balkan, Ponto-Caspian (brackish water), east Siberian, Pacific, and Atlantic. Turkey is located within the Ponto-Caspian region. 
The Oligochaeta is a large group of annelid worms that inhabit terrestrial, freshwater and marine environments. While earthworms (Crassiclitellata and Moniligastridae) and enchytraeids (Enchytraeidae) are mainly terrestrial, taxa in the other 14 families are predominantly aquatic (Timm 2017). Timm (1980) reported that 700 limicolous and 100 true marine oligochaete species are known worldwide. However, this number has greatly increased because of other recent studies (e.g., Erséus 1979; Timm 1980; Erséus 1981; Dumnicka 1983; Erséus 1984; Brinkhurst et al. 1994; Erséus 1997; Arslan et al. 2006; Matamoros et al. 2007; Timm 2013; Arslan et al. 2018). Timm (2017) published an annoted catalogue, which included 1081 new nominal taxa and 372 new combinations or names with new ranks of available scientific names given to the oligochaetes in freshwater and marine families that were described since the publication of the monograph by Brinkhurst \& Jamieson (1971) and its supplement (Brinkhurst \& Wetzel 1984).

Although studies on the aquatic oligochaete fauna of Turkey have increased over the last 20+ years, the diversity of oligochaete species still remains unclear. To date, one branchiobdellidan, 150 oligochaete and six aphanoneuran species have been reported. Although several scientists have described new taxa from Turkey, this number is undoubtedly lower than estimated. The reason is that Turkey is the only country covering almost entirely 3 out of 34 global biodiversity hotspots (Caucasus, Irano-Anatolian, and Mediterranean). Their geographical locations, with mountains acting as an isolation barrier for aquatic organisms as well the characteristics of its peninsulas, support a high biodiversity. In Turkey, there are numerous disconnected rivers, and lakes are commonly separated from each other by mountains. One of those lakes is Lake Çıldır, located in the northern part of East Anatolia. In recent years, several studies have focused on the freshwater oligochaetes of the Turkish lakes and rivers, but to date no study has focused specifically on the oligochaete fauna of Lake Çıldır.

In this paper, we discuss the oligochaete fauna of Lake Çıldır in northeastern Turkey based on our recent survey, then we present an updated list of freshwater annelid species that have been recorded from the country, including distributional information and citations for papers in which those species were presented.

\section{Material and Methods}

\section{Study area}

Lake Ç1ldır ( $\left.41^{\circ} 04^{\prime} \mathrm{N}, 43^{\circ} 12^{\prime} \mathrm{E}\right)$ is located in northeastern part of Turkey. It's a large freshwater lake between Kars and Ardahan provinces (Figure 1). The surface area of the Lake is $124 \mathrm{~km}^{2}$ and has a maximum depth of around $40 \mathrm{~m}$ (Alkan et al. 2016). Its altitude is $1959 \mathrm{~m}$. The surface of the lake is ice-covered for approximately 6-7 months. Lake Çıldır has IBA (important bird area) and IPA (important plant area) status due to the fact that it is home to two rare birds - the Ruddy shelduck (Tadorna ferruginea (Pallas)) and the Armenian gull (Larus armenicus Buturlin), and three rare plants-Carex limosa (Linnaeus), Potamogeton alpinus (Balbis), Scholochloa festucacea (Willd.), and Sparganium minimum Wallr.

\section{Sampling}

In this present study, 116 oligochaete specimens were collected from the lake between July-August 2017 using hand net or Ekman grab sampler (with coverage of $225 \mathrm{~cm}^{2}$ ), one haul per station. In addition, some physico-chemical parameters of surface water were measured in situ by using Hach Lange HQ40D. After the samples were processed in the field using a series of sieves with decreasing mesh sizes, specimens were extracted from raw samples in lab, under a dissecting microscope, and transferred to $70 \%$ ethyl alcohol. Specimens were prepared for the identification either in glycerin or polyvinyl lactophenol. Taxonomic identifications of oligochaetes followed the keys and species diagnoses presented in Brinkhurst and Jamieson (1971), Brinkhurst and Wetzel (1984), Sperber (1948, 1950), Kathman and Brinkhurst (1998) and Timm (1999).

\section{Literature review: aquatic Oligochaetes and other annelids occuring in Turkey}

The first study on the freshwater oligochaete fauna of Turkey was published by Sperber (Sperber 1958). Martínez-Ansemil \& Giani (1987) indicated that the occurrence of Limnodrilus hoffmeisteri Claparède in Turkey was mentioned in Naidu (Naidu 1965). Since 1949, several Turkish scientists have contributed to the knowledge of the aquatic oligochaetes of Turkey.

We completed an extensive review of historical and recent literature focusing on studies of aquatic fauna 
in Turkey, specifically those including freshwater oligochaetes and other annelids. Distributional and habitat information for these species as presented in those publications has been summarized and is presented in the Appendix. The list of oligochaetes in the Appendix does not include records or other information discussed in unpublished MSc and PhD theses, nor those pertinent to soil forms (e.g., Lumbricidae and Enchytraeidae). However, species considered to be primarily terrestrial, but are occasionally collected from semi-aquatic habitats have been included in the Appendix. The primary focus of this study was to evaluate the oligochaete fauna of Lake Çıldır, which had no previous studies on Annelida fauna, and to then integrate the results of that study to compile an updated list of oligochaete species that had been presented in historical as well as recent publications.

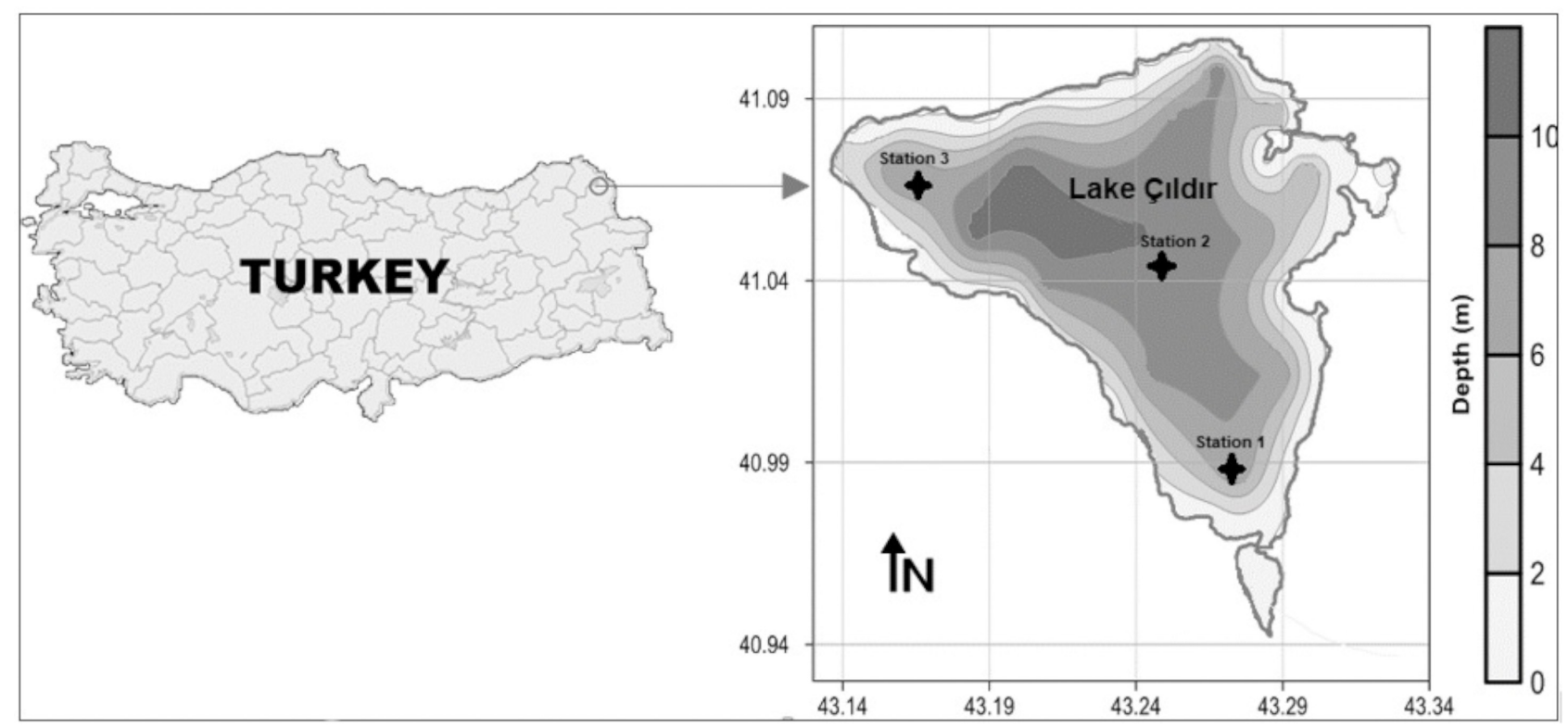

FIGURE 1: Geographical position of Lake Çıldır in Turkey, with location of sampling points (this map was modified from Alkan et al. 2016).

\section{Results and Conclusions}

\section{The Oligochaete fauna of Lake Çıldır}

In the present study, a total of 22 oligochaete species were identified from Lake Çıldır. All identified species are new records for Lake Çıldır (Table 1). Although oligochaete species identified in this study were reported several times from different parts of Turkey, four species-Chaetogaster diastrophus (Gruithuisen), Uncinais uncinata (Ørsted), Spirosperma velutinus (Grube) and Stylodrilus parvus (Hrabě \& Cernosvitov)—were reported from only a few locations (see Appendix). Two other species, Peipsidrilus libanus (Giani et al.) and Tubifex acuticularis Martínez-Ansemil \& Giani, first described as new to science from Lebanon by Giani $e t$ al. (1982) and Martínez-Ansemil \& Giani (1983), are reported herein from Turkey for only the second time. Arslan et al. (2007) had previously collected each of these two species from Göksu River (Balıkdamı wetland). These two species were recorded during this present study from Lake Çıldır (Turkey), suggesting that Tubifex acuticularis and Peipsidrilus libanus may have a wider distribution in the Near East.

\section{Remarks on two oligochaete taxa occurring in Lake Çıldır}

Tubifex sp.: Specimen length 5.3-9.8 mm, genital segments in X-XI. Segment number 42-63. Prostomium not obtuse and clitellum inconspicuous, no coelomocytes. In dorsal bundles 2-4 hair seta and 3-4 pectinate seta, upper and lower toot equal. Hair chaetae smooth anteriorly but slightly serrate posteriorly. Ventral bundles contain bifid chaetae, 4-5 per bundle (anteriorly), 2-3 (posteriorly). Male genitalia paired in X-XI, 
vas deferens longer than atrium. Atrium comma shaped. In segment X, testes paired, ovaries in XI, spermatozeugmata present.

This species is similar to Tubifex blanchardi Vejdovský form (Holmquist 1983; Marotta et al. 2014), but it has a few different structures. In this study this specimen was listed as Tubifex sp. since the exact species identification will be done following the DNA analysis.

Potamothrix alatus Finogenova: Among the identified oligochaete species in the Lake Çıldır, another interesting species is Potamothrix alatus whose taxonomic status based on specimens collected during this study is still uncertain. Several morphological features of the $P$. alatus specimens collected from Lake Çıldır are similar to two previously described subspecies ( $P$. alatus paravanicus Poddubnaja $\&$ Pataridze and $P$. alatus hazaricus Timm \& Arslan) yet have different morphological characteristics from these two subspecies. This taxon is listed as $P$. alatus for this study; we hope that DNA sequencing will determine whether specimens of this taxon collected during this study are identical to $P$. alatus paravanicus or P. alatus hazaricus or represent a separate subspecies. Potamothrix a. paravanicus was identified as a different species from Lakes Paravani, Sagamo and Sevan. However, it was then revised as a subspecies of P. alatus (Poddubnaja \& Pataridze 1989; Finogenova \& Poddubnaja 1990). Potamothrix alatus hazaricus was described in Lake Hazar (Arslan et al. 2013), which is close to Lake Çıldır. Potamothrix alatus hazaricus differs morphologically from $P$. a. paravanicus, the former has a different structure with lateral wings in the genital region of the body. The genital segments of $P$. a. hazaricus X-XI almost always have large, lateral wing-like protrusions. These "wings" start anteriorly in the dorsolateral part of X and continue in XI (Arslan et al. 2013), while lateral wing-like protrusions of $P$. alatus, a morphology observed on specimens collected from sites Çıldır Lake sites, are only present in XI and not as large or as wide as those observed on $P$. a. hazaricus specimens. The differences of $P$. alatus in Lake Çıldır were not only in the genital region, but also in the hair, pectinate and ventral chaetae that were located in the ventral and dorsal bundles. Nuclear TSI and mitochondrial COI analyses appear to be a prerequisite for them to be defined as a different subspecies.

TABLE 1. Composition of oligochaete species and some environmental parameters for 3 sampling points in Lake Çıldır during the research period (July-August 2017). Numerals across the species show the individual number of oligochaete species collected.

\begin{tabular}{|c|c|c|c|c|}
\hline & \multirow[t]{2}{*}{ Parameters } & \multicolumn{3}{|c|}{ Sampling sites } \\
\hline & & 1 & 2 & 3 \\
\hline & \multirow[t]{2}{*}{ Latitude and longitude coordinates } & $40^{\circ} 59^{\prime} 28.83^{\prime \prime} \mathrm{N}$ & $41^{\circ} 022^{\prime} 38.92^{\prime \prime} \mathrm{N}$ & $41^{\circ} 03^{\prime} 45.62^{\prime \prime} \mathrm{N}$ \\
\hline & & $43^{\circ} 56^{\prime} 16.72^{\prime \prime} \mathrm{E}$ & $43^{\circ} 15^{\prime} 46.57^{\prime \prime} \mathrm{E}$ & $43^{\circ} 10^{\prime} 12.96^{\prime \prime} \mathrm{E}$ \\
\hline & Hydrogen Ion Concentration (as $\mathrm{pH}$ ) & 7.8 & 8.2 & 8.1 \\
\hline & Dissolved oxygen $\left(\mathrm{mg} \mathrm{l}^{-1}\right)$ & 7.6 & 8.7 & 9.3 \\
\hline & Depth $(m)$ & 3 & 12 & $5-$ \\
\hline & Surface water temperature $\left({ }^{\circ} \mathrm{C}\right)$ & 18 & 20 & $19-$ \\
\hline & \multicolumn{4}{|l|}{ Oligochaeta species } \\
\hline & \multicolumn{4}{|l|}{ Naidinae } \\
\hline 1 & Chaetogaster diastrophus (Gruithuisen, 1828) & 4 & - & 1 \\
\hline 2 & Paranais frici Hrabě, 1941 & 2 & 1 & - \\
\hline 3 & Uncinais uncinata (Ørsted, 1842) & 25 & 32 & 54 \\
\hline 4 & Stylaria lacustris (Linnaeus, 1767) & 4 & 15 & 7 \\
\hline 5 & Nais elinguis Müller, 1773 & 2 & 5 & 3 \\
\hline 6 & Nais communis Piguet, 1906 & - & 1 & 4 \\
\hline 7 & Nais variabilis Piguet, 1906 & 2 & - & - \\
\hline 8 & Nais pardalis Piguet, 1906 & 3 & - & 4 \\
\hline 9 & Nais simplex Piguet, 1906 & 2 & - & - \\
\hline
\end{tabular}

...Continued on the next page 
TABLE 1. (Continued)

\begin{tabular}{|c|c|c|c|c|}
\hline & \multirow[t]{2}{*}{ Parameters } & \multicolumn{3}{|c|}{ Sampling sites } \\
\hline & & 1 & 2 & 3 \\
\hline & \multicolumn{4}{|l|}{ Tubificinae } \\
\hline 10 & Tubifex tubifex (Müller, 1774) & 3 & 5 & 2 \\
\hline 11 & Tubifex sp. & 2 & 4 & - \\
\hline 12 & Tubifex acuticularis Martínez-Ansemil \& Giani, 1983 & 3 & 2 & - \\
\hline 13 & Peipsidrilus libanus (Giani et al., 1982) & - & - & 4 \\
\hline 14 & Limnodrilus hoffmeisteri Claparède, 1862 & 6 & 2 & - \\
\hline 15 & Spirosperma velutinus (Grube, 1879) & 2 & - & - \\
\hline 16 & Haber speciosus (Hrabě, 1931) & - & - & 4 \\
\hline 17 & Potamothrix hammoniensis (Michaelsen, 1901) & 3 & - & 3 \\
\hline 18 & Potamothrix bavaricus (Oschmann, 1913) & - & 2 & - \\
\hline 19 & Potamothrix alatus Finogenova, 1972 & 2 & 1 & 2 \\
\hline \multirow[t]{2}{*}{20} & Psammoryctides albicola (Michaelsen, 1901) & 2 & - & - \\
\hline & Lumbriculidae & & & \\
\hline \multirow[t]{2}{*}{21} & Stylodrilus parvus (Hrabě \& Černosvitov, 1927) & 4 & - & - \\
\hline & Enchytraeidae & & & \\
\hline 22 & Enchytraeus albidus (Henle, 1837) & 2 & - & - \\
\hline
\end{tabular}

\section{Checklist of Turkish fauna}

In summarizing the data presented in the publications annotated in Appendix and complimented by the survey of oligochaete species recently collected from Lake Çıldır (Table 1), 150 oligochaete, 1 branchiobdellidan and 6 aphanoneuran species are now known to occur in Turkey. Several scientists have described new taxa from Turkey, yet we believe additional taxa, including as yet undescribed species, have yet to be discovered in the country, which certainly could include one or more cosmopolitan species. According to the distribution charts prepared by Timm (Timm 1980), it can be emphasized that among these 157 freshwater annelid species recorded from Turkey, 23 species-Aeolosoma variegatum Vejdovský, Slavina appendiculata (D’Udekem), Dero digitata (Müller), Dero furcatus (Müller), Dero obtusa (d'Udekem), Nais elinguis, Nais communis, Nais variabilis, Chaetogaster limnaei von Baer, Chaetogaster langi Bretscher, Pristina longiseta Ehrenberg, Pristina aequiseta Bourne, Pristina jenkinae (Stephenson), Pristina proboscidea Beddard, Tubifex tubifex, Limnodrilus hoffmeisteri, Limnodrilus udekemianus Claparède, Limnodrilus claparedeanus Ratzel, Rhyacodrilus coccineus (Vejdovský), Aulodrilus pigueti Kowalewski, Aulodrilus limnobius Bretscher, Lumbriculus variegatus (Müller), and Eiseniella tetraedra (Savigny)—have cosmopolitan or wide distribution. Apart from these, Chaetogaster diastrophus, Nais elinguis, Allonais pectinata (Stephenson), and Aulodrilus pluriseta (Piguet) were also considered to be cosmopolitan species by Spencer (Spencer 1980). All of these species had previously been recorded from different areas in Turkey. In addition, many European species (e.g., Paranais frici, Potamothrix hammoniensis, Ophidonais serpentina (Müller), and Vejdovskyella comata (Vejdovský)) and transholarctic species (e.g., Stylaria lacustris, Uncinais uncinata, Chaetogaster diaphanus, Limnodrilus profundicola (Verrill)) were recorded from Turkey several times by different authors (see Appendix). These transholarctic species have also been reported from the Sino-Indian region (Timm 1980). Eight species (Paranais litoralis (Müller), Paranais frici, Nais simplex, Nais pseudobtusa Piguet, Vejdovskyella comata, Tubifex ignotus (Stolc), Ilyodrilus templetoni (Southern), and Bothrioneurum vejdovskyanum (Štolc) have been recorded as being Holarctic, yet their known distribution includes the Ethiopian region (Spencer 1980). These eight species were also recorded in Turkey. Several oligochaete species occurring in Turkey show similarities to the communities in neighboring regions.

The uniqueness of Turkey with respect to its mountainous regions act as an isolation barrier for aquatic 
organisms, and the characteristics of its peninsulas have contributed to the country's in high biodiversity. There are numerous disconnected rivers in the country, and lakes are separated from one another by mountains, including Lake Ç1ldır, which is located in the northern part of East Anatolia. Surveys of new as well as understudied aquatic and semi-aquatic habitats in Turkey will certainly result in the discovery of new distributional records and, as well, new species to science.

\section{Acknowledgements}

This study was supported by Eskisehir Osmangazi University Scientific Research Projects Committee (Project number: 201619A224). Many thanks to ISAO editors of this proceedings for their assistance during the review process.

\section{References}

Akbulut, M., Çelik E.Ş., Odabaşı D.A., Kaya, H., Selvi, K., Arslan, N. \& Odabaşı, S. (2009) Seasonal distribution and composition of benthic macroinvertebrate communities in Menderes Creek, Çanakkale, Turkey. Fresenius Environmental Bulletin, 18 (11a), 2136-2145.

Alkan, A., Gökçek, Ç., Akbaş, U. \& Alkan, N. (2016) Spatial Distributions of Heavy Metals in the Water and Sediments of Lake Çıldır, Turkey. Ekoloji, 25, 98, 9-16. https://doi.org/10.5053/ekoloji.2015.23

Anonymous. (1993) Türkiye'nin Sulak Alanları. Türkiye Çevre Vakfı (TÇV) Yayınları, Önder Matbaasi, Ankara, 398 pp.

Aras, S. \& Fındık, O. (2016) The aquatic oligochaetes (Annelida: Clitellata) of eight lakes in the Aşağı Fırat River Basin (Lower Euphrates, Turkey). Biologia 71 (1), 38-43. https://doi.org/10.1515/biolog-2016-0001

Arslan, N. (2006) Littoral Fauna of Oligochaeta (Annelida) of Lake Eğirdir (Isparta). Ege University Journal of Fisheries \& Aquatic Sciences, 23 (3-4), 315-319.

Arslan, N. \& Ahıska, S. (2007) Manyas Gölü Oligochaeta (Annelıda) Faunasının Taksonomik Açıdan Belirlenmesine Yönelik Bir Ön Araştırma. Türk Sucul Yaşam Dergisi, 3-5, (5-8), 278-285.

Arslan, N. \& İlhan, S. (2010) Distribution and abundance of Oligochaeta (Annelida) species and environmental variables of Porsuk Stream (Sakarya River, Turkey). Review of Hydrobiology, 3 (1), 51-63.

Arslan, N., İlhan, S., Şahin, Y., Filik, C., Yılmaz, V. \& Öntürk, T. (2007) Diversity of Invertebrate Fauna in Littoral of Shallow Musaözü Dam Lake in Comparison with Environmental Parameters. Journal of Applied Biological Sciences, 1 (3), 67-75.

Arslan, N. \& Şahin Y. (2006) A preliminary study on the identification of the Littoral Oligochaete (Annelida) and Chironomidae (Diptera) fauna of Lake Kovada, a national park in Turkey. Turkish Journal of Zoology, 30, 67-72.

Arslan, N. \& Şahin, Y. (2004) First records of some Naididae (Oligochaeta) species for Turkey. Turkish Journal of Zoology, 28, $7-18$.

Arslan, N. \& Şahin, Y. (2003) Two new records of Aulodrilus Bretscher, 1899 (Oligochaeta, Tubificidae) for the Turkish fauna. Turkish Journal of Zoology, 27, 3, 275-280.

Arslan, N., Kara, D., Akkan Kökçü, C. \& Rüzgar, M. (2014) Aquatic Oligochaeta (Annelida) of Dam Lakes Çatören and Kunduzlar (Turkey). Zoosymposia, 9, 70-76. https://doi.org/10.11646/zoosymposia.9.1.12

Arslan, N., Kara, D. \& Odabaşı, D.A (2013) Twelve new records (Clitellata, Chironomidae and Gastropoda) from Lake Gölbaş1 (Hatay-Turkey). Turkish Journal of Fisheries and Aquatic Sciences, 13, 869-873. https://doi.org/10.4194/1303-2712-v13_5_11

Arslan, N., Kökmen-Aras, S. \& Mercan, D. (2018) An indigenous species, Dreissena polymorpha (Pallas, 1771) (Mollusca, Bıvalvı), as an invader in Lake Büyük Akgöl. Transylvanian Review of Systematical and Ecological Research, 20.2, "The Wetlands Diversity", 39-50. https://doi.org/10.2478/trser-2018-0011

Arslan, N., Salur, A., Kalyoncu, H., Mercan, D., Barışık, B. \& Odabaşı, D.A. (2016) The use of BMWP and ASPT indices for evaluation of water quality according to macroinvertebrates in Küçük Menderes River (Turkey). Biologia, 71 (1), $49-57$. https://doi.org/10.1515/biolog-2016-0005

Arslan, N., Timm, T. \& Erséus, C. (2006) Aquatic Oligochaeta (Annelida) of Balıkdamı wetland (Turkey), with description of two new species of Phallodrilinae. Biologia, Bratislava, 62/3, 323-334. https://doi.org/10.2478/s11756-007-0055-y 
Arslan, N., Timm, T., Rojo, V., Vizcaíno, A. \& Schmelz, R.M. (2018) A new species of Enchytraeus (Enchytraeidae, Oligochaeta) from the profundal of Lake Van, the world's largest soda Lake (Turkey, East Anatolia). Zootaxa, 4382 (2), 367-380.

https://doi.org/10.11646/zootaxa.4382.2.8

Balık, S., Ustaoğlu, M.R. \& Sarı, M.H. (1999) Kuzey Ege Bölgesi’ndeki akarsuların faunası üzerine ilk gözlemler. Ege Üniversitesi Su Ürünleri Dergisi, 16, 289-299.

Balık, S., Ustaoğlu, M.R. \& Yıldız, S. (2004) Oligochaeta and Aphanoneura (Annelida) Fauna of the Gediz Delta (Menemenİzmir). Turkish Journal of Zoology, 28, 183-197.

Balık, S., Ustaoğlu, M.R., Özbek, M., Yıldız, S., Taşdemir, A. \& İlhan, A. (2006a) Küçük Menderes Nehri'nin (Selçuk, İzmir) Așağı Havzası'ndaki Kirliliğin Makro Bentik Omurgasızlar Kullanılarak Saptanması. Ege Üniversitesi Su Ürünleri Dergisi, 23 (1-2), 61-65.

Balık, S., Ustaoğlu, M.R., Sarı, H.M., Özdemir Mis, D., Aygen, C., Taşdemir, A., Yıldız, S., Topkara, E.T., Sömek, H., Özbek, M. \& İlhan, A. (2006b) A preliminary study on the biological diversity of Bozalan Lake (Menemen- İzmir). Ege Üniversitesi Su Ürünleri Dergisi, 23 (3-4), 291-294.

Balık, S., Ustaoğlu, M.R., Taşdemir, A. \& Yıldız, S. (2000) Işıklı Gölü (Çivril-Denizli) bentik faunası. In: XV Ulusal Biyoloji Kongresi, Cilt I, Ankara, pp. 210-216.

Balık, S., Ustaoğlu, M.R., Taşdemir, A., Yıldız, S., Özbek, M. (2005) A preliminary study on the macrobenthic invertebrate fauna of Kuş Lake (Bandırma). Ege Üniversitesi Su Ürünleri Dergisi, 22 (3-4), 347-349.

Balık, S., Ustaoğlu, M.R., Yıldız, S. \& Taşdemir, A. (2001) Benthic fauna (Oligochaeta-Chironomidae) of Sazlıgöl L. (Menemen-İzmir). In: XI. Ulusal Su Ürünleri Sempozyumu Bildirileri, Hatay, pp. 198-205.

Barlas, M., Yılmaz, F., İmamoğlu, Ö. \& Akkoyun, Ö. (2000) Physico-chemical and biological investigation of Yuvarlak Stream within the Köyceğiz district of Muğla. In: Su Ürünleri Sempozyumu, 249-265.

Brinkhurst, R.O. \& Jamieson, B.G.M. (1971) Aquatic Oligochaeta of the World. Oliver and Boyd, Edinburgh, 860 pp.

Brinkhurst, R.O. \& Wetzel, M.J. (1984) Aquatic Oligochaeta of the World: Supplement. A Catalogue of New Freshwater Species, Descriptions, and Revisions. Canadian Technical Report of Hydrography and Ocean Sciences No. 44. Institute of Ocean Sciences, Sidney, British Columbia, Canada, 101 pp.

Brinkhurst, R.O., Rodriguez, P., Tae-Soo, C. \& Tae-Sung, K. (1994) A new genus of Lumbriculidae (Oligochaeta) from Korea. Canadian Journal of Zoology, 72, 1960-1966. https://doi.org/10.1139/z94-267

Çamur-Elipek, B., Arslan, N., Kırgız, T. \& Öterler, B. (2006) Benthic macrofauna in Tunca River (Turkey) and their relationships with environmental variables. Acta hydrochimica et hydrobiologica, 34, 360-366. https://doi.org/10.1002/aheh.200500631

Çamur-Elipek, B., Arslan, N., Kırgız, T., Öterler, B., Güher, H. \& Özkan, N. (2010) Analysis of benthic macroinvertebrates in relation to environmental variables of Lake Gala, a national park of Turkey. Turkish Journal of Fisheries and Aquatic Sciences, 10, 235-243. https://doi.org/10.4194/trjfas.2010.0212

Çapraz, S. \& Arslan, N. (2005) The Oligochaeta (Annelida) Fauna of Aksu Stream (Antalya). Turkish Journal of Zoology, 29, 229-236.

Çetinkaya, O., Sarı, M., Şen, F., Arabacı, M. \& Duyar, H. A. (1994) Limnological characteristics of Karasu River inflowing Lake Van. Yüzüncü Yıl Üniversitesi, Ziraat Fakültesi Dergisi, 4, 151-168.

Dumnicka, E. (1983) Tubificidae (Oligochaeta) from Subterranean waters, with description of two new genera. Bijdragen tot de Dierkunde, 53, 2, 255-261. https://doi.org/10.1163/26660644-05302008

Duran, M., Tüzen, M., \& Kayım, M. (2003) Exploration on biological richness and water quality of Stream Kelkit, TokatTurkey. Fresenius Environmental Bulletin, 12, 4, 368-375.

Erséus, C. (1979) Taxonomic revision of the marine genus Phallodrilus pierantoni (Tubificidae, Oligochaeta) with description of thirteen new species. Zoologica Scripta, 8, 187-208. https://doi.org/10.1111/j.1463-6409.1979.tb00631.x

Erséus, C. (1981) Taxonomic studies of Phallodrillinae (Oligochaeta, Tubificidae) from the Great Barrier Reef and the Comoro Islands with descriptions of ten new species and one new genus. Zoologica Scripta, 10, 15-32. https://doi.org/10.1111/j.1463-6409.1981.tb00481.x

Erséus, C. (1984) Taxonomy and phylogeny of the gutless Phallodrilinae (Oligochaeta, Tubificidae) with descriptions of one new genus and twenty-two new species. Zoologica Scripta, 13, 4, 239-272. https://doi.org/10.1111/j.1463-6409.1984.tb00041.x

Erséus, C. (1997) Marine Tubificidae (Oligochaeta) from the Montebello and Houtman Abrolhos Islands, Western Australia, with descriptions of twenty-three new species. In 'The Marine Flora and fauna of the Houtman Abrolhos Islands, Western 
Australia'. (Ed. FE Wells). (Western Australian Museum: Perth).

Findık, O. \& Aras, S. (2016) Aquatic oligochaetes (Annelida: Clitellata) of seven lakes in the Ceyhan River basin (Turkey). Biologia, 71 (1), 44-48. https://doi.org/10.1515/biolog-2016-0007

Finogenova, N.P. \& Poddubnaja, T.L. (1990) One more revision of the genus Potamothrix Vejdovský et Mrázek, 1902 (Oligochaeta, Tubificidae). Zoologische Jahrbücher, Abteilung für Systematik, Ökologie und Geographie der Tiere, 117, 55-83.

Geldiay, R. \& Tareen, I.U. (1972) Bottom fauna of Gölcük Lake. Scientific Reports of the Faculty of Science, Ege University No:137, pp.1-15.

Geldiay, R. (1949) Çubuk Barajı ve Emir Gölü’nün makro ve mikrofaunasının mukayeseli incelenmesi. Ankara Üniversitesi Fen Fakultesi Mecmuası 2, Ankara, 106 pp.

Giani, N., Martínez-Ansemil, E., \& Moubayed, Z. (1982) Les Oligochètes aquatiques du Liban. I. — Neoaulodrilus libanus n. g., n. sp. et Nais iorensis Pataridze, 1957. Annales de Limnologie, 18, 179-190. https://doi.org/10.1051/limn/1982019

Holmquist, C. (1983) A revision of the genera Tubifex Lamarck, Ilyodrilus Eisen, and Potamothrix Vejdovský \& Mrázek (Oligochaeta, Tubificidae), with extensions to some connected genera. Zoologische Jahrbücher, Abteilung für Systematik, Ökologie und Geographie der Tiere, 112, 311-366.

Hrabě, S. (1981) Vodní máloštětinatci (Oligochaeta) Československa. Acta Universitatis Carolinae Biologica, 167 pp.

International Union for Conservation of Nature 2018 Biodiversity of Turkey. Available from: https://www.iucn.org/content/ biodiversity-turkey (Accessed on 24 July 2018)

The Nature Conservancy 2015 Freshwater Ecoregions of the World. Available from: http://www.feow.org (Accessed on 24 July 2018)

Karașahin, B. \& Yıldırım, M.Z. (2000) Karacaören I Baraj Gölünün benthik faunası üzerine bir araştırma [abstract]. In: $X V^{t h}$ National Congress on Biology "with international participation”. September 5-9, Ankara Turkey.

Kathman, R.D. \& Brinkhurst R.O. (1998). Guide to the freshwater Oligochaetes of North America. Aquatic Resources Center, Tennessee, USA, 264 pp.

Kazanc1, N. \& Girgin, S. (1998) Distribution of Oligochaeta species as bioindicators of organic pollution in Ankara Stream and their use in biomonitoring. Turkish Journal of Zoology, 22, 83-87.

Kazancı, N., Girgin, S., Dügel, B., Mutlu, Ş., Barlas, M. \& Özçelik, M. (2000) Türkiye Gölleri: Köyceğiz, Beyşehir, Eğirdir, Akşehir, Eber, Çorak, Kovada, Yarışlı, Bafa, Salda, Karataş, Çavuşçu Gölleri, Küçük ve Büyük Menderes Deltası, Güllük Sazlığı, Karamuk Bataklı̆̆ı'nın Limnolojisi, Çevre Kalitesi ve Biyolojik Çeşitliliği. (CD -Room).

Kırgız, T. (1989) The bottom fauna of Gala Lake. Anadolu Üniversitesi Fen-Edebiyat Fakültesi Dergisi, I, 67-87.

Kırgız, T., Çamur-Elipek, B. \& Arslan, N. (2005) Preliminary study of Enchytraeidae (Oligochaeta) in the Tunca River (Thrace, Turkey). Proceedings of the Estonian Academy of Science: Biology, Ecology, 54 (4), 310-314.

Kökmen, S., Arslan, N., Filik, C. \& Yilmaz, V. (2007) Zoobenthos of Lake Uluabat, a Ramsar Site in Turkey, and Their Relationship with Environmental Variables. Clean, 35 (3), 266-274. https://doi.org/10.1002/clen.200700006

Marotta, R., Crottini, A., Raimondi, E., Fondello, C. \& Ferraguti, M. (2014) Alike but different: the evolution of the Tubifex tubifex species complex (Annelida, Clitellata) through polyploidization. BMC Evolutionary Biology, 14, 73. https://doi.org/10.1186/1471-2148-14-73

Martínez-Ansemil, E. \& Giani, N. (1983) Les oligochètes du Liban. V. Tubifex acuticularis n. sp. (Tubificidae). Annales de Limnologie, 19 (3), 203-206. https://doi.org/10.1051/limn/1983023

Martínez-Ansemil, E. \& Giani, N. (1987) The distribution of aquatic Oligochaetes in south and eastern Maditerranean area. Hydrobiologia, 155, 293-303. https://doi.org/10.1007/BF00025662

Matamoros, L., Yıldız, S. \& Erséus, C. (2007) A new species within the genus Marionina (Enchytraeidae: Annelida: Clitellata) from the southern Black Sea. Marine Biology Research, 3 (6), 397-402. https://doi.org/10.1080/17451000701694844

Moubayed, Z., Giani, N. \& Martínez-Ansemil, E. (1987) Distribution of Aquatic Oligochaeta and Aphanoneura in the Near East. In: Beihefte zum Tübinger Atlas des Vorderen Orients, ser. A, L. Reichert Pub., Wiesbaden 28, pp. 80-90.

Naidu, K.V. (1965) Studies on freshwater Oligochaeta of South India. II. Tubificidae. Hydrobiologia, 26, 463-483. https://doi.org/10.1007/BF00045539

Odabașı, S., Arslan, N. \& Cirik, S. (2017) A new Rhyacodrilin (Oligochaeta) record (Bothrioneurum vejdovskyanum Štolc, 1886) for Turkey. Süleyman Demirel Üniversitesi Eğirdir Su Ürünleri Fakültesi Dergisi, 13(2), 179-185. https://doi.org/10.22392/egirdir.293118 
Odabaşı, S., Arslan, N. \& Odabaş1, D.A (2016). First Record of Branchiobdella kozarovi Subchev, 1978 from European Part of Turkey. Acta zoologica bulgarica, 68 (4), 597-598.

Odabașı, S., Odabaşı, D.A. \& Arslan N. (2015) The first record of Chaetogaster limnaei limnaei Baer 1827 (Annelida: Clitellata) on Pseudobithynia yildirimi (Gastropoda: Prosobranchia) from northwest of Turkey. Turkish Journal of Fisheries and Aquatic Sciences, 15, 367-369.

Omodeo, P. (1987) Some new species of Haplotaxidae (Oligochaeta) from Guinea and remarks on the history of the family. Hydrobiologia, 155, 1-13. https://doi.org/10.1007/BF00025626

Omodeo, P. (1956) Oligocheti dell' Indocina e del mediterraneo orientale. Memorie del Museo Civico di Storia Naturale di Verona 5, pp: 321-336.

Öntürk, T. \& Arslan, N. (2003) A preliminary study for the determination on the Oligochaeta and Chironomidae fauna of Gümüş Stream (Mardin-Kızıltepe) [abstract]. In: XII. Ulusal Su Ürünleri Sempozyumu, 2-5 September, Elazı̆̆g, Turkey, p. 131.

Özbek, M., Taşdemir, A. \& Yıldız, S. (2016) Adıgüzel Baraj Gölü (Denizli-Türkiye)'nün bentik makroomurgasızları. Ege Journal of Fisheries and Aquatic Sciences, 33(3), 259-263. https://doi.org/10.12714/egejfas.2016.33.3.10

Poddubnaja, T.L. \& Pataridze, A.I. (1989) A new species of the genus Potamothrix (Oligochaeta, Tubificidae) from the high mountain lakes of the Caucasus. Zoologičeskij Žurnal, 68 (10), 153-156. [In Russian, with English Summary]

Polatdemir Arslan, N. \& Şahin, Y. (2003) Nine new Naididae (Oligochaeta) species for Sakarya River, Turkey. Turkish Journal of Zoology, 27, 27-38.

Pop, V. (1974) Faunistische Forschungen in den Grundwässern des Nahen Ostens. XII. Oligochaeta (Annelida). Archiv für Hydrobiologie, 73, 108-121.

https://doi.org/10.1127/archiv-hydrobiol/73/1974/108

Şahin, Y. \& Baysal, A. (1972) Benthic fauna of Lake Hazar and its distribution. Publications of the Hydrobiological Research Institute, Faculty of Science, University of İstanbul, 9, 1-33.

Şahin, S.K. \& Yıldız, S. (2011) Species distribution of oligochaetes related to environmental parameters in Lake Sapanca (Marmara Region, Turkey). Turkish Journal of Fisheries and Aquatic Sciences, 11(3), 359-366.

Sözen, M. \& Yiğit, S. (1999) The benthic fauna and some limnological aspects of Lake Akşehir (Konya). Turkish Journal of Zoology, 23, 829-847.

Spencer, D.R. (1980) The Aquatic Oligochaeta of the St. Lawrence Great Lakes region. In: Brinkhurst, R.O. and Cook, D. G. (eds). Aquatic Oligochaete Biology. Plenum Press, New York, 115-164. https://doi.org/10.1007/978-1-4613-3048-6_8

Sperber, C. (1948) A taxonomical study of the Naididae. Zoology, Bidrag, Uppsala Bd, 28, 1-296.

Sperber, C. (1950) A guide for the determination of European Naididae. Zoology, Bidrag, Uppsala Bd, 29, 45-78.

Sperber, C. (1958) Über einige Naididae aus Europa, Asien und Madagaskar. Archiv für Zoologie, 12, 45-53.

Şekercioğlu, C.H., Anderson, S., Akçay, E., Bilgin, R., Emre Can, Ö., Semiz, G., Tavşanoğlu, Ç., Baki Yokeş, M., Soyumert, A. \& İpekdal, K. (2011) Turkey's globally important biodiversity in crisis. Biological Conservation, 144, 2752-2769. https://doi.org/10.1016/j.biocon.2011.06.025

Tanatmış, M. (1989) The preliminary studies on limnofauna of invertebrate in Enne Stream (Porsuk River). Anadolu Üniversitesi Fen-Edebiyat Fakültesi Dergisi, I, 15-35.

Taş, M., Çamur-Elipek, B., Kırgız, T., Arslan, N. \& Yıldız, S. (2012) The Aquatic and Semi-Aquatic Oligochaeta Fauna of Turkish Thrace Region. Journal of Fisheries.sciences.com, 6 (1), 26-31. https://doi.org/10.3153/jfscom.2012004

Taş, M., Kırgız, T. \& Arslan, N. (2011) Dynamics of Oligochaeta fauna in Sazlıdere Stream (Edirne, Turkey) with relation to environmental factors. Acta zoologica bulgarica, 63 (2), 179-185.

Taş, M., Kırgız, T., Arslan, N., Çamur-Elipek, B. \& Güher, H. (2008) Çorlu Deresi’nin (Tekirdağ) Oligochaeta Faunası ve Bazı Fizikokimyasal Özelliklerinin Zamana Bağlı Değişimi. Ege University Journal of Fisheries \& Aquatic Sciences, 25 (4), 253-257.

Taşdemir, A., Yıldız, S., Özbek, M., Ustaoğlu, M. R. \& Balık, S. (2010) Tahtalı Baraj Gölü’nün (İzmir) Makrobentik (Oligochaeta, Chironomidae, Amphipoda) Faunas1. Journal of Fisheries Science.com, 4 (4), 376-383. https://doi.org/10.3153/jfscom.2010040

Timm, T. (1980) Distribution of aquatic oligochaetes. In: Brinkhurst, R.O. \& Cook, D. G. (Eds), Aquatic Oligochaete Biology. Plenum Press, New York, pp. 55-77. https://doi.org/10.1007/978-1-4613-3048-6_6

Timm, T. (1999) A guide to the Estonian Annelida. Naturalist's Handbooks 1, Tart-Tallin, 208 pp.

Timm, T. (2013) The genus Potamothrix (Annelida, Oligochaeta, Tubificidae): a literature review. Estonian Journal of Ecology, 
62, 121-136.

https://doi.org/10.3176/eco.2013.2.04

Timm, T. (2017) Aquatic microdrile Oligochaeta (Annelida, Clitellata): New nominal taxa and combinations since 1984. Zootaxa, 4282 (3), 401-452.

https://doi.org/10.11646/zootaxa.4282.3.1

Timm, T., Arslan, N., Rüzgar, M., Martinsson, S. \& Erséus, C. (2013) Oligochaeta (Annelida) of the profundal of Lake Hazar (Turkey), with description of Potamothrix alatus hazaricus n. ssp. Zootaxa, 3716 (2), 144-156. https://doi.org/10.11646/zootaxa.3716.2.2

Topkara, E.T., Taşdemir, A. \& Yıldız, S. (2018) Karagöl (Dikili-İzmir)'ün Bentik Makroomurgasız Faunası Üzerine Bir Araștırma. Süleyman Demirel Üniversitesi Eğirdir Su Ürünleri Fakültesi Dergisi, 14 (1), 34-41. https://doi.org/10.22392/egirdir.318317

Ustaoğlu, M.R., Balık, S., Özbek, M., Taşdemir, A. \& Yıldız, S. (2004) Buldan Baraj Gölü (Denizli)'nün Bentik Omurgasız Faunası. Ege Üniversitesi Su Ürünleri Dergisi, Cilt 21 (1-2).

Ustaoğlu, M.R., Balık, S., Sarı, H.M., Mis, D., Aygen, C., Özbek, M., İlhan, A., Taşdemir, A., Yıldız, S. \& Topkara, E.T. (2008) Uludağ (Bursa)'daki Buzul Gölleri ve Akarsularının Faunası. Ege Üniversitesi Su Ürünleri Dergisi, 25 (4), $295-299$.

Ustaoğlu, R. (1980) Karagölün (Yamanlar-İzmir) bentik faunası (Oligochaeta, Chaoboridae, Chironomidae) üzerine araştırmalar. TUBITAK VIII. Bilim Kongresi, Matematik Fiziki ve Biyolojik Bilimler Araştırma Grubu Tebliğleri, pp. 331344.

Yıldız, S. \& Ahıska, S. (2010) Nais stolci Hrabě, 1981: a new oligochaete (Annelida: Clitellata: Naididae) species for Turkey. Turkish Journal of Zoology, 34 (4), 547-549.

Yıldız, S. \& Balık, S. (2005) The Oligochaeta (Annelida) Fauna of The Inland Waters in the Lake District (Turkey). Ege University Journal of Fisheries and Aquatic Sciences, 22 (1-2), 165-172.

Yıldız, S. \& Balık, S. (2006) The Oligochaeta (Annelida) Fauna of Topçam Dam-Lake (Aydın-Turkey). Turkish Journal of Zoology, 30 (1), 83-89.

Yıldız, S. \& Balık, S. (2010) Nais christinae Kasprzak, 1973, an Oligochaeta species new for Turkey. Zoology in the Middle East, 50, 151-152. https://doi.org/10.1080/09397140.2010.10638432

Yıldız, S. \& Ustaoğlu, M.R. (2016) Denizli’deki Dağ Göllerinin Oligochaeta (Annelida) Faunası Üzerine Gözlemler (in Turkish with English abstract). Ege Journal of Fisheries and Aquatic Sciences, 33 (2), 89-96. https://doi.org/10.12714/egejfas.2016.33.2.01

Yıldız, S., Özbek, M., Taşdemir, A. \& Balık, S. (2010a) Identification of predominant environmental factors structuring benthic macroinvertebrate communities: A case study in the Küçük Menderes coastal wetland (Turkey). Fresenius Environmental Bulletin, 19 (1), 30-36.

Yıldız, S., Özbek, M., Taşdemir, A. \& Topkara, E.T. (2015) Assessment of a shallow montane Lentic Ecosystem (Lake Gölcük, İzmir, Turkey) using Benthic Community Diversity. Ekoloji, 24, 1-13. https://doi.org/10.5053/ekoloji.2015.34

Yıldız, S., Özbek, M., Ustaoğlu, M.R. \& Sömek, H. (2012) Distribution of Aquatic Oligochaetes (Annelida: Clitellata) of high elevation lakes in the Eastern Black Sea Range of Turkey. Turkish Journal of Zoology, 36 (1), 59-74.

Yıldız, S., Tașdemir, A., Balık, S. \& Ustaoğlu, M.R. (2008) Kemer Baraj Gölü’nün (Aydın) Makrobentik (Oligochaeta, Chironomidae) Faunasi. Journal of Fisheries Sciences.com, 2 (3), 457-465.

Yıldız, S., Taşdemir, A., Özbek, M., Balık, S. \& Ustaoğlu, M.R. (2005) Macrobenthic Fauna of Lake Eğrigöl (GündoğmuşAntalya). Turkish Journal of Zoology, 29, 275-282.

Yıldız, S., Ustaoğlu, M.R. \& Balık, S. (2007a) Contributions to the knowledge of Oligochaeta (Annelida) fauna of some mountain lakes on the Taurus Range (Turkey). Turkish Journal of Zoology, 31, 249-254.

Yıldız, S., Ustaoğlu, M.R. \& Balık, S. (2007b) The Oligochaeta (Annelida) fauna of Yuvarlak stream (Köyceğiz-Turkey). Turkish Journal of Fisheries and Aquatic Sciences, 7 (1), 01-06.

Yıldız, S., Ustaoğlu, M.R. \& Balık, S. (2007c) Türkiye'deki Bazı Lagünlerin Oligochaeta (Annelida) Faunası Hakkında Bir Ön Araştırma. Ulusal Su Günleri 2007 Sempozyumu, 16-18 Mayıs 2007, Antalya, Türk Sucul Yaşam Dergisi, 5-8, $217-223$.

Yıldız, S., Ustaoğlu, M.R. \& Balık, S. (2009) Akgöl ve Gebekirse Gölleri’nin (Selçuk-İzmir) Oligochaeta (Annelida) Faunası. Review of Hydrobiology, 2, 173-186.

Yıldız, S., Ustaoğlu, M.R. \& Balık, S. (2009) Ötrof Bir Dağ Gölü’nün Faunası'na Katkılar: İkizgöl (Bornova-İzmir) Oligoketleri (Annelida).

Yıldız, S., Ustaoğlu, M.R. \& Balık, S. (2010b) Littoral Oligochaeta (Lumbriculidae and Enchytraeidae) communities of some mountain lakes in the Eastern Black Sea range (Turkey). Zoology in the Middle East, Supplementum 2, Advances in Earthworm Taxonomy, 151-160. https://doi.org/10.1080/09397140.2010.10638468 
Yıldız, S., Ustaoğlu, M.R., Balık, S. \& Sarı, H.M. (2008) Contributions to the Knowledge of Oligochaeta (Annelida) Fauna of Some Lakes in the West Black Sea Region (Turkey). Journal of the Black Sea-Mediterranean Environment, 14(3), 193204.

Zeybek, M., Ahıska, S. \& Yıldız, S. (2016) A preliminary taxonomical investigation on the Oligochaeta (Annelida) fauna of Tigris River (Turkey) (in Turkish with English abstract). Ege Journal of Fisheries and Aquatic Sciences, 33(1), 47-53. https://doi.org/10.12714/egejfas.2016.33.1.08

Zeybek, M., Koşal Şahin, S. \& Yıldız, S. (2018) The Aquatic Oligochaeta (Annelida) Fauna of the Karasu Stream. Journal of Limnology and Freshwater Fisheries Research, 4 (1), 30-35. https://doi.org/10.17216/limnofish.363933

Appendix. List of Aphanoneura, Branchiobdellida and Oligochaeta species reported from different aquatic systems of Turkey, including the results of this present study in Lake Çıldır (abbreviations used in this Appendix-S.: stream, L.: lake, R.: river, DL: Dam lake, TML: Taurus Mountains's lake, WBSL: West Black Sea Lakes, GL: Glasier Lake, CW: Coastal Wetland, EBSL: Eastern Black Sea Lakes; EHEBSL: Eastern High Elevation Black Sea Lakes, TTRR: Thrace Region Rivers).

\begin{tabular}{|c|c|c|}
\hline & Taxa & Literature data \\
\hline Phylum & Annelida & \\
\hline Subclass & Branchiobdellida & \\
\hline Order & Branchiobdellida & \\
\hline 1 & $\begin{array}{l}\text { Branchiobdella kozarovi Subchev, } \\
1978\end{array}$ & Yenikarpuzlu Pond- Edirne (Odabaşı et al. 2016); \\
\hline Subclass & Oligochaeta & \\
\hline Order & Crassiclitellata & \\
\hline Family & Criodrilidae & \\
\hline 2 & Criodrilus lacuum Hoffmeister, 1845 & Emir L. (Geldiay, 1949); \\
\hline Order & Enchytraeida & \\
\hline Family & Enchytraeidae & \\
\hline 3 & Achaeta sp. & Balıkdamı Wetland (Arslan et al. 2006); \\
\hline 4 & $\begin{array}{l}\text { Cognettia sphagnetorum (Vejdovský, } \\
1878)\end{array}$ & $\begin{array}{l}\text { EBSL (Yıldız et al. 2010b); EHEBSL (Yıldız et al. 2012); TTRR (Taş } \\
\text { et al. 2012); Denizli mountain lakes (Yıldız \& Ustaoğlu 2016); Tigris R. } \\
\text { (Zeybek et al. 2016); Tunca R. (Çamur-Elipek et al. 2006); Tunca R. } \\
\text { (Kırgız et al. 2005); }\end{array}$ \\
\hline 5 & $\begin{array}{l}\text { Cognettia glandulosa (Michaelsen, } \\
\text { 1889) }\end{array}$ & $\begin{array}{l}\text { EBSL (Yıldız et al. 2010b); EHEBSL (Yıldız et al. 2012); TTRR (Taş } \\
\text { et al. 2012); Denizli mountain lakes (Yıldız \& Ustaoğlu 2016); Tigris R. } \\
\text { (Zeybek et al. 2016); Tunca R (Çamur-Elipek et al. 2006); Tunca R. } \\
\text { (Kırgız et al. 2005); }\end{array}$ \\
\hline 6 & Cognettia sp. & $\begin{array}{l}\text { TTRR (Taş et al. 2012); Tunca R. (Çamur-Elipek et al. 2006); Tunca R. } \\
\text { (Kırgız et al. 2005); }\end{array}$ \\
\hline 7 & $\begin{array}{l}\text { Enchytraeus polatdemiri Arslan \& } \\
\text { Timm, } 2018\end{array}$ & Van L. (Arslan et al. 2018); \\
\hline 8 & Enchytraeus albidus (Henle, 1837) & $\begin{array}{l}\text { Sazlıgöl L. (Balık et al. 2001); Gediz Delta (Balık et al. 2004); Çıldır L. } \\
\text { (Arslan \& Mercan present study); }\end{array}$ \\
\hline 9 & $\begin{array}{l}\text { Enchytraeus buchholzi Vejdovský, } \\
1879\end{array}$ & $\begin{array}{l}\text { Localities? (Pop 1974); Işıklı L. (Balık et al. 2000); TTRR (Taş et al. } \\
\text { 2012); Tunca R. (Çamur-Elipek et al. 2006); Tunca R. (Kırgız et al. } \\
\text { 2005); }\end{array}$ \\
\hline 10 & $\begin{array}{l}\text { Enchytraeus coronatus Nielsen and } \\
\text { Christensen, } 1959\end{array}$ & Yuvarlak R. (Yıldız et al. 2007b); \\
\hline
\end{tabular}




\section{Taxa}

Phylum Annelida

11 Enchytraeus sp.

$12 \quad$ Frederica sp.

$$
\text { Henlea perpusilla Friend, } 1911
$$

\section{Family Propappidae}

\section{Family Haplotaxidae}

25 Haplotaxis gordioides (Hartmann, 1821)

\section{Order Lumbriculida \\ Family Lumbriculidae}

Lumbriculus sp.

\section{Literature data}

Locality? (Pop 1974); Gölcük L. (Geldiay \& Tareen 1972); Buldan L. (Ustaoğlu et al. 2004); Eğrigöl L. (Yıldız et al. 2005);

Ankara S. (Moubayed et al. 1987); TTRR (Taş et al. 2012); Tunca R. (Çamur-Elipek et al. 2006); Tunca R. (Kırgız et al. 2005); Denizli mountain lakes (Yıldız \& Ustaoğlu 2016);

Lake District Region (Yıldız \& Balık 2005); Yuvarlak R. (Yıldız et al. 2007b); EBSL (Yıldız et al. 2010b); Tigris R. (Zeybek et al. 2016);

Lake District Region (Yıldız \& Balık 2005); Tigris R. (Zeybek et al. 2016);

EBSL (Yıldız et al. 2010b); TTRR (Taş et al. 2012); Karagöl L. (Topkara et al. 2018); Tunca R. (Çamur-Elipek et al. 2006); Tunca R. (Kirgiz et al. 2005);

EBSL (Yıldiz et al. 2010b); EHEBSL (Yıldız et al. 2012);

Gediz Delta (Balık et al. 2004);

Gediz Delta (Balık et al. 2004);

TTRR (Taş et al. 2012); Tunca R. (Çamur-Elipek et al. 2006);

Specific locality information not included in publication (Pop 1974);

Sinop (Matamoros et al. 2007);

Lake District Region (Yıldız \& Balık 2005); EBSL (Yıldız et al. 2010); EHEBSL (Yildiz et al. 2012);

Yuvarlak R. (Yild1z et al. 2007b); EBSL (Y1ld1z et al. 2010b); EHEBSL (Yıldız et al. 2012); Tigris R. (Zeybek et al. 2016);

Tunca R. (Kırgız et al. 2005); Tunca R. (Çamur-Elipek et al. 2006); TTRR (Taş et al. 2012);

Antakya (Omedeo 1987); Ankara S. (Kazancı \& Girgin 1998); Lake District Region (Yıldız \& Balık 2005); EHEBSL (Yıldız et al. 2012); TTRR (Taş et al. 2012); Eğirdir L. (Arslan 2006); Balıkdamı Wetland (Arslan et al. 2006); Porsuk R. (Arslan \& İlhan 2010);

Işıklı L. (Balık et al. 2000); Kelkit S. (Duran et al. 2003); Lake District Region (Yıldız \& Balık 2005); TML (Yıldız et al. 2007a); Yuvarlak R. (Y1ldiz et al. 2007b); EBSL (Y1ldiz et al. 2010b); EHEBSL (Y1ldız et al. 2012); Denizli mountain lakes (Yı1dız \& Ustaoğlu 2016); İkizgöl (Yıldız et al. 2009); Eğirdir L. (Arslan 2006); Musaözü DL (Arslan et al. 2007); Porsuk R. (Arslan \& İlhan 2010);

Gölcük L. (Geldiay \& Tareen 1972); Karamuk L. (Anonymous 1993); Eğirdir; Bafa and Eber L.; Büyük Menderes Delta (Kazancı et al. 2000); Balıkdamı Wetland (Arslan et al. 2006); Uluabat L. (Kökmen et al. 2007); 


\section{Phylum Annelida}

\begin{tabular}{ll}
\hline 29 & Rhynchelmis sp. \\
Family & Naidinae \\
30 & Allonais pectinata (Stephenson, 1910) \\
31 & $\begin{array}{l}\text { Allonais gwaliorensis (Stephenson, } \\
1910)\end{array}$ \\
32 & Amphichaeta leydigii Tauber, 1879 \\
33 & Amphichaeta sannio Kallstenius, 1892 \\
34 & $\begin{array}{l}\text { Chaetogaster diaphanus (Gruithuisen, } \\
\text { 1828) }\end{array}$
\end{tabular}

Porsuk R. (Arslan \& İlhan 2010);

Sakarya R. (Arslan \& Şahin 2004);

Sakarya R. (Arslan \& Şahin 2004); Yuvarlak R. (Yıldız et al. 2007b);

Gediz Delta (Balık et al. 2004); Buldan L. (Ustaoğlu et al. 2004);

Gediz Delta (Balık et al. 2004);

Işıklı L. (Balık et al. 2000); Sakarya R. (Arslan \& Şahin 2004); TML (Yıldız et al. 2007a); Yuvarlak R. (Yıldız et al. 2007); EHEBSL (Yıldız et al. 2012); Aksu R. (Çapraz \& Arslan 2005); Porsuk R. (Arslan \& İlhan 2010);

35 Chaetogaster diastrophus (Gruithuisen, 1828)

Yuvarlak R. (Yildiz et al. 2007b); Balıkdamı Wetland (Arslan et al. 2006); Sazlıdere S. (Taş et al. 2011); Çıldır L. (Arslan \& Mercan present study);

$36 \quad$ Chaetogaster langi Bretscher, 1896

37 Chaetogaster limnaei von Baer, 1827

38 Chaetogaster limnaei limnaei von Baer, 1827

39 Chaetogaster sp.

$40 \quad$ Dero borelli Michaelsen, 1900

$41 \quad$ Dero dorsalis Ferroinére, 1899

42 Dero digitata (Müller, 1773)

43 Dero furcatus (Müller, 1774)

Sakarya R. (Arslan \& Şahin 2004);

Gölcük L. (Geldiay \& Tareen 1972);

Tuzla S. (Odabaşı et al. 2015);

EHEBSL (Y1ldiz et al. 2012);

Sakarya R. (Arslan \& Şahin 2004);

Sazlı̈öl L. (Balık et al. 2001); İkizgöl (Yıldız et al. 2009); Ceyhan River Basin Lakes (Findık \& Aras 2016);

Işıklı L. (Balık et al. 2000); Sazlıgöl L. (Balık et al. 2001); Gediz Delta (Balık et al. 2004); Kuş L. (Balık et al. 2005); Eğrigöl L. (Yıldız et al. 2005); Lake District Region (Yıldız \& Balık 2005); Küçük Menderes R. (Balık et al. 2006a); Topçam DL (Yıldız \& Balık 2006); Yuvarlak R. (Yıldız et al. 2007b); WBSL (Yıldız et al. 2008); Küçük Menderes CW (Yıldız et al. 2010a); TTRR (Taş et al. 2012); Denizli mountain lakes (Yıldız \& Ustaoğlu 2016); Gölcük L. (Yıldız et al. 2015); Akgöl L. (Yıldız et al. 2009); İkizgöl (Yıldız et al. 2009); Aksu R. (Çapraz \& Arslan 2005); Kovada L. (Arslan \& Şahin 2006); Tunca R. (ÇamurElipek et al. 2006); Musaözü DL (Arslan et al. 2007); Uluabat L. (Kökmen et al. 2007); Manyas L. (Arslan \& Ahıska 2007); Çorlu R. (Taş et al. 2008); Menderes R. (Akbulut et al. 2009); Sazlıdere S. (Taş et al. 2011); Çatören and Kunduzlar DL (Arslan et al. 2014); Büyük Akgöl L. (Arslan et al. 2018); Euphrates R. (Aras \& Findık 2016); Ceyhan River Basin Lakes (Findık \& Aras 2016);

Sakarya R. (Arslan \& Şahin 2004); Buldan L. (Ustaoğlu et al. 2004); TTRR (Taş et al. 2012); Aksu R. (Çapraz \& Arslan 2005); Tunca R. (Çamur-Elipek et al. 2006); Eğirdir L. (Arslan 2006); Balıkdamı Wetland (Arslan et al. 2006); Musaözü DL (Arslan et al. 2007); Sazlıdere S. (Taş et al. 2011); Çatören and Kunduzlar DL (Arslan et al. 2014); Ceyhan River Basin Lakes (Findık \& Aras 2016);

$44 \quad$ Dero obtusa d'Udekem, 1855

Gediz Delta (Balık et al. 2004); Lake District Region (Yıldız \& Balık 2005); Topçam DL (Yıldız \& Balık 2006); Yuvarlak R. (Yıldız et al. 2007b); WBSL (Yıldız et al. 2008); Çorlu R. (Taş et al. 2008); Euphrates R. (Aras \& Fındık 2016); 


\section{Taxa}

\section{Phylum Annelida}

$45 \quad$ Homochaeta naidina Bretscher, 1896

46

47

48

Nais communis Piguet, 1906

Nais alpina Sperber, 1948

Nais barbata Müller, 1773

Nais behningi Michaelsen, 1923

Nais bretscheri Michaelsen, 1899

\section{Literature data}

Gediz S. (Balık et al. 1999); Işıklı L. (Balık et al. 2000); Gediz Delta (Balık et al. 2004);

Homochaeta setosa (Moszynski, 1933) Gediz Delta (Balık et al. 2004);

Yuvarlak R. (Yild1z et al. 2007b);

Sakarya R. (Arslan \& Şahin 2004); Lake District Region (Yıldız \& Balık 2005); Yuvarlak R. (Yıldız et al. 2007b); WBSL (Yıldız et al. 2008); Tigris R. (Zeybek et al. 2016); Kovada L. (Arslan \& Şahin 2006); Musaözü DL (Arslan et al. 2007); Uluabat L. (Kökmen et al. 2007); Porsuk R. (Arslan \& İlhan 2010); Sazlıdere S. (Taș et al. 2011); Küçük Menderes R. (Arslan et al. 2016);

Yuvarlak R. (Yıldız et al. 2007b); WBSL (Yıldız et al. 2008); Tigris R. (Zeybek et al. 2016);

Sakarya R. (Arslan \& Şahin 2004); Gümüş S. (Öntürk \& Arslan 2003); Yuvarlak R. (Yıldız et al. 2007b); Tigris R. (Zeybek et al. 2016); Aksu R. (Çapraz \& Arslan 2005); Eğirdir L. (Arslan 2006); Musaözü DL (Arslan et al. 2007); Menderes R. (Akbulut et al. 2009); Porsuk R. (Arslan \& İlhan 2010); Sazlıdere S. (Taş et al. 2011);

Sakarya R. (Arslan \& Şahin 2004); Lake District Region (Yıldız \& Balık 2005); Yuvarlak R. (Yild1z et al. 2007b); WBSL (Y1ld1z et al. 2008); Sapanca L. (Şahin \& Yıldız 2011); EHEBSL (Yıldız et al. 2012); EHEBSL (Yıldız et al. 2012); TTRR (Taş et al. 2012); Tigris R. (Zeybek et al. 2016); Aksu R. (Çapraz \& Arslan 2005); Kovada L. (Arslan \& Şahin 2006); Tunca R. (Çamur-Elipek et al. 2006); Eğirdir L. (Arslan 2006); Balıkdamı Wetland (Arslan et al. 2006); Musaözü DL (Arslan et al. 2007); Uluabat L. (Kökmen et al. 2007); Manyas L. (Arslan \& Ahıska 2007); Menderes R. (Akbulut et al. 2009); Porsuk R. (Arslan \& İlhan 2010); Gala L. (Çamur-Elipek et al. 2010); Büyük Akgöl L. (Arslan et al. 2018); Euphrates R. (Aras \& Findık 2016); Ceyhan River Basin Lakes (Fındık \& Aras 2016); Çıldır L. (Arslan \& Mercan present study);

Gümüldür R. (Yıldız \& Balık 2010);

Ankara S. (Moubayed et al. 1987); Sakarya R. (Arslan \& Şahin 2004); Gediz Delta (Balık et al. 2004); Lake District Region (Yıldız \& Balık 2005); Küçük Menderes R. (Balık et al. 2006a); Yuvarlak R. (Yıldız et al. 2007b); WBSL (Yıldız et al. 2008); Küçük Menderes CW (Yıldız et al. 2010a); EHEBSL (Y1ldiz et al. 2012); EHEBSL (Y1ld1z et al. 2012); TTRR (Taș et al. 2012); Denizli mountain lakes (Yıldız \& Ustaoğlu 2016); Tigris R. (Zeybek et al. 2016); Tunca R. (Çamur-Elipek et al. 2006); Eğirdir L. (Arslan 2006); Balıkdamı Wetland (Arslan et al. 2006); Musaözü DL (Arslan et al. 2007); Manyas L. (Arslan \& Ahıska 2007); Çorlu R. (Taş et al. 2008); Menderes R. (Akbulut et al. 2009); Porsuk R. (Arslan \& İlhan 2010); Sazlıdere S. (Taş et al. 2011); Çatören and Kunduzlar DL (Arslan et al. 2014); Küçük Menderes R. (Arslan et al. 2016); Çıldır L. (Arslan \& Mercan present study); 


\section{Taxa}

\section{Phylum Annelida}

$54 \quad$ Nais pardalis Piguet, 1906

\section{Literature data}

Sivas (Sperber 1958); Sakarya R. (Polatdemir Arslan \& Şahin 2003); Gümüș S. (Öntürk \& Arslan 2003); Lake District Region (Yıldız \& Balık 2005); Küçük Menderes R. (Balık et al. 2006a); Yuvarlak R. (Yıldız et al. 2007b); WBSL (Yıldız et al. 2008); Kemer DL (Yıldız et al. 2008); Uludağ GL (Ustaoğlu et al. 2008); Küçük Menderes CW (Yıldı et al. 2010a); EHEBSL (Yıldız et al. 2012); EHEBSL (Yıldız et al. 2012); TTRR (Taş et al. 2012); Adıgüzel DL (Özbek et al. 2016); Tigris R. (Zeybek et al. 2016); Aksu R. (Çapraz \& Arslan 2005); Kovada L. (Arslan \& Şahin 2006); Tunca R. (Çamur-Elipek et al. 2006); Balıkdamı Wetland (Arslan et al. 2006); Musaözü DL (Arslan et al. 2007); Porsuk R. (Arslan \& İlhan 2010); Küçük Menderes R. (Arslan et al. 2016); Çıldır L. (Arslan \& Mercan present study);

Sakarya R. (Arslan \& Şahin 2004); Lake District Region (Yıldız \& Balık 2005); Yuvarlak R. (Yildız et al. 2007b); WBSL (Yıldız et al. 2008); EHEBSL (Yildiz et al. 2012); EHEBSL (Yıldız et al. 2012); Tigris R. (Zeybek et al. 2016); Balıkdamı Wetland (Arslan et al. 2006); Porsuk R. (Arslan \& İlhan 2010);

Sakarya R. (Arslan \& Şahin 2004); Yuvarlak R. (Yıldız et al. 2007b); WBSL (Y1ld1z et al. 2008); EHEBSL (Y1ld1z et al. 2012); EHEBSL (Yıldız et al. 2012); Tigris R. (Zeybek et al. 2016); Balıkdamı Wetland (Arslan et al. 2006); Euphrates R. (Aras \& Findık 2016); Ceyhan River Basin Lakes (Fındık \& Aras 2016); Çıldır L. (Arslan \& Mercan present study);

Tigris R. (Y1ldız \& Ahıska 2010);

Ayva keuy? (Sperber 1958); Sakarya R. (Polatdemir Arslan \& Şahin 2003); Gümüș S. (Öntürk \& Arslan 2003); Lake District Region (Yıldız \& Balık 2005); Küçük Menderes R. (Balık et al. 2006a); Yuvarlak R. (Yıldız et al. 2007b); WBSL (Yıldız et al. 2008); Küçük Menderes CW (Yıldız et al. 2010a); TTRR (Taş et al. 2012); Tigris R. (Zeybek et al. 2016); Aksu R. (Çapraz \& Arslan 2005); Tunca R. (Çamur-Elipek et al. 2006); Eğirdir L. (Arslan 2006); Balıkdamı Wetland (Arslan et al. 2006); Musaözü DL (Arslan et al. 2007); Uluabat L. (Kökmen et al. 2007); Manyas L. (Arslan \& Ahıska 2007); Menderes R. (Akbulut et al. 2009); Porsuk R. (Arslan \& İlhan 2010); Gala L. (Çamur-Elipek et al. 2010); Çatören and Kunduzlar DL (Arslan et al. 2014); Çıldır L. (Arslan $\&$ Mercan present study);

Gölcük L. (Geldiay \& Tareen 1972); Ankara S. (Kazancı \& Girgin 1998); EHEBSL (Y1ld1z et al. 2012); EHEBSL (Y1ld1z et al. 2012); Ceyhan River Basin Lakes (Fındık \& Aras 2016);

Ophidonais serpentina (Müller, 1773)
Afchin? (Sperber 1958); Gölcük L. (Geldiay \& Tareen 1972); Tigris basin and West of Ceyhan channel (Moubayed et al. 1987); Sakarya R. (Polatdemir Arslan \& Şahin 2003); Işıklı L. (Balık et al. 2000); Sazlıgöl L. (Balık et al. 2001); Lake District Region (Yıldız \& Balık 2005); Yuvarlak R. (Yıldız et al. 2007b); WBSL (Yıldız et al. 2008); Uludağ GL (Ustaoğlu et al. 2008); EHEBSL (Yıldız et al. 2012); TTRR (Taș et al. 2012) ; Tigris R. (Zeybek et al. 2016); Kovada L. (Arslan \& Şahin 2006); Eğirdir L. (Arslan 2006); Musaözü DL (Arslan et al. 2007); Manyas L. (Arslan \& Ahıska 2007); Çorlu R (Taş et al. 2008); Porsuk R. (Arslan \& İlhan 2010); Sazlıdere S. (Taș et al. 2011); Büyük Akgöl L. (Arslan et al. 2018); 


\section{Taxa}

\section{Phylum Annelida}

61 Paranais botniensis Sperber, 1948

62 Paranais frici Hrabě, 1941

Paranais litoralis (Müller, 1784)

64

65

66

Pristinella jenkinae (Stephenson, 1931)

Pristina longiseta Ehrenberg, 1931

Pristina proboscidea Beddard, 1896

Pristinella acuminata Liang, 1958

Pristinella amphibiotica (Lastočkin, 1927)

Pristinella bilobata (Bretscher, 1903)

\section{Literature data}

Gediz Delta (Balık et al. 2004); Yuvarlak R. (Yıldız et al. 2007b); Sakarya R. (Arslan \& Şahin 2004); Gümüş S. (Öntürk \& Arslan 2003); Gediz Delta (Balık et al. 2004); Lake District Region (Yıldız \& Balık 2005); Küçük Menderes R. (Balık et al. 2006a); TML (Yıldız et al. 2007a); Yuvarlak R. (Yıldız et al. 2007b); Küçük Menderes CW (Yıldız et al. 2010a); Sapanca L. (Şahin \& Yıldız 2011); TTRR (Taş et al. 2012); Kovada L. (Arslan \& Şahin 2006); Tunca R. (Çamur-Elipek et al. 2006); Eğirdir L. (Arslan 2006); Balıkdamı Wetland (Arslan et al. 2006); Uluabat L. (Kökmen et al. 2007); Menderes R. (Akbulut et al. 2009); Çatören and Kunduzlar DL (Arslan et al. 2014); Çıldır L. (Arslan \& Mercan present study);

Gediz Delta (Balık et al. 2004); Yuvarlak R. (Yıldız et al. 2007b);

Gediz Delta (Balık et al. 2004);

Gediz Delta (Balık et al. 2004);

Sakarya R. (Polatdemir Arslan \& Şahin 2003); Yuvarlak R. (Yildız et al. 2007b); Tigris R. (Zeybek et al. 2016); Eğirdir L. (Arslan 2006); Balıkdamı Wetland (Arslan et al. 2006); Uluabat L. (Kökmen et al. 2007); Porsuk R. (Arslan \& İlhan 2010); Büyük Akgöl L. (Arslan et al. 2018); Ceyhan River Basin Lakes (Findık \& Aras 2016);

Bozova and Antalya (Pop 1974);

Erekli; Insirti? (Sperber 1958); locality? (Pop 1974); Sakarya R. (Polatdemir Arslan \& Şahin 2003); Küçük Menderes R. (Balık et al. 2006a); WBSL (Yıldız et al. 2008);

Locality? (Pop 1974); Sakarya R. (Polatdemir Arslan \& Şahin 2003); Porsuk R. (Arslan \& İlhan 2010); Sazlıdere S. (Taş et al. 2011);

Muğla (Pop 1974); Sakarya R. (Polatdemir Arslan \& Şahin 2003);

Işıklı L. (Balık et al. 2000); Yuvarlak R. (Yıldız et al. 2007b); Lake District Region (Yıldız \& Balık 2005);

Sakarya R. (Arslan \& Şahin 2004); Gediz Delta (Balık et al. 2004);

Sakarya R. (Arslan \& Şahin 2004); Gediz S. (Balık et al. 1999); Sazlıgöl L. (Balık et al. 2001); Gediz Delta (Balık et al. 2004); TML (Yıldız et al. 2007a); Yuvarlak R. (Yıldız et al. 2007b); TTRR (Taş et al. 2012); Tunca R. (Çamur-Elipek et al. 2006);

Erekli; Khodja Ali? (Sperber 1958); Sakarya R. (Polatdemir Arslan \& Şahin 2003); Yuvarlak R. (Yıldız et al. 2007b); TTRR (Taş et al. 2012); Aksu R. (Çapraz \& Arslan 2005); Kovada L. (Arslan \& Şahin 2006); Tunca R. (Çamur-Elipek et al. 2006); Eğirdir L. (Arslan 2006); Balıkdamı Wetland (Arslan et al. 2006); Musaözü DL (Arslan et al. 2007); Manyas L. (Arslan \& Ahıska 2007); Porsuk R. (Arslan \& İlhan 2010); Çatören and Kunduzlar DL (Arslan et al. 2014);

Yarim Bourghaz? (Sperber 1958); Sakarya R. (Arslan \& Şahin 2004); Gediz S. (Balık et al. 1999); Buldan L. (Ustaoğlu et al. 2004); Yuvarlak R. (Yildiz et al. 2007b); WBSL (Yildiz et al. 2008); 


\section{Taxa}

\section{Phylum Annelida}

$76 \quad$ Pristinella osborni (Walton,1906)

Pristinella rosea (Piguet, 1906)

78

79

80

81

Stylaria lacustris (Linnaeus, 1767)

Stylaria fossularis Leidy, 1852 1884) 1896)

\section{Literature data}

Işıklı L. (Balık et al. 2000); Sakarya R. (Arslan \& Şahin 2004); Lake District Region (Yıldız \& Balık 2005); WBSL (Yıldız et al. 2008); Denizli mountain lakes (Yıldız \& Ustaoğlu 2016); Tigris R. (Zeybek et al. 2016); Aksu R. (Çapraz \& Arslan 2005);

Sakarya River (Arslan \& Şahin 2004); Yuvarlak R. (Yıldız et al. 2007b); Porsuk R. (Arslan \& İlhan 2010); Ceyhan River Basin Lakes (Fındık \& Aras 2016);

Sakarya R. (Arslan \& Şahin 2004); Yuvarlak R. (Yıldız et al. 2007b);

Sakarya R. (Arslan \& Şahin 2004); Ișıklı L. (Balık et al. 2000); Gediz Delta (Balık et al. 2004); WBSL (Yıldız et al. 2008); Sazlıdere S. (Taş et al. 2011);

Spericaria josinae (Vejdovský, 1884)

Sakarya R. (Arslan \& Şahin 2004);

Gölcük L. (Geldiay \& Tareen 1972); Sakarya R. (Arslan \& Şahin 2004); Işıklı L. (Balık et al. 2000); Lake District Region (Yıldız \& Balık 2005); WBSL (Y1ldiz et al. 2008);

Tigris basin (Moubayed et al. 1987); Gediz and Güzelhisar S. (Balık et al. 1999); Ișıklı L. (Balık et al. 2000); Sakarya R. (Polatdemir Arslan \& Şahin 2003); Gediz Delta (Balık et al. 2004); Lake District Region (Yıldız \& Balık 2005); Yuvarlak R. (Yıldız et al. 2007b); WBSL (Yıldız et al. 2008); TTRR (Taş et al. 2012); Tigris R. (Zeybek et al. 2016); Aksu R. (Çapraz \& Arslan 2005); Kovada L. (Arslan \& Şahin 2006); Tunca R. (Çamur-Elipek et al. 2006); Eğirdir L. (Arslan 2006); Balıkdamı Wetland (Arslan et al. 2006); Musaözü DL (Arslan et al. 2007); Uluabat L. (Kökmen et al. 2007); Manyas L. (Arslan \& Ahiska 2007); Çorlu R. (Taş et al. 2008); Porsuk R. (Arslan \& İlhan 2010); Sazlıdere S. (Taş et al. 2011); Çatören and Kunduzlar DL (Arslan et al. 2014); Küçük Menderes R. (Arslan et al. 2016); Büyük Akgöl L. (Arslan et al. 2018); Euphrates R. (Aras \& Findık 2016); Ceyhan River Basin Lakes (Fındık \& Aras 2016); Çıldır L. (Arslan \& Mercan present study);

Sakarya R. (Arslan \& Şahin 2004); Gediz S. (Balık et al. 1999); Yuvarlak R. (Yıldiz et al. 2007b); EHEBSL (Y1ld1z et al. 2012); EHEBSL (Yıldız et al. 2012); Uluabat L. (Kökmen et al. 2007); Çatören and Kunduzlar D.L. (Arslan et al. 2014); Çıldır L. (Arslan \& Mercan present study);

Işıklı L. (Balık et al. 2000); Gediz Delta (Balık et al. 2004);

Vejdovskyella intermedia (Bretscher,

Ayva keuy? (Sperber 1958);

Upper Sakarya R. (Arslan \& Şahin 2003); Gediz Delta (Balık et al. 2004); Lake District Region (Yıldız \& Balık 2005); Topçam DL (Yıldız \& Balık 2006); Some Lagune L. (Yıldız et al. 2007c); EHEBSL (Yıldız et al. 2012); TTRR (Taş et al. 2012); Denizli mountain lakes (Yıldız \& Ustaoğlu 2016); Karasu R. (Zeybek et al. 2018); Akgöl L. (Yıldız et al. 2009); Aksu R. (Çapraz \& Arslan 2005); 


\section{Phylum Annelida}

$87 \quad$ Aulodrilus pluriseta (Piguet, 1906)
Bothrioneurum vejdovskyanum Štolc, 1886

Branchiura sowerbyi Beddard, 1892

Coralliodrilus amissus Arslan, Timm \& Erséus, 2007

Epirodrilus moubayedi Giani \& Martínez-Ansemil, 1983

Gianius anatolicus Arslan, Timm \& Erséus, 2007

Haber speciosus (Hrabě,1931)

Haber swirencowi (Jaroschenko, 1948) Heterochaeta costata Claparède, 1863 Ilyodrilus templetoni (Southern,1909)

Ilyodrilus frantzi Brinkhurst, 1965

Ilyodrilus sp.

Isochaetides $\mathrm{sp}$.

Limnodrilus claparedeianus Ratzel, 1868
Upper Sakarya R. (Arslan \& Şahin 2003); Gediz Delta (Balık et al. 2004); Lake District Region (Yıldız \& Balık 2005); Küçük Menderes R. (Balık et al. 2006a); TML (Yıldız et al. 2007a); WBSL (Yıldız et al. 2008); Küçük Menderes CW (Yıldız et al. 2010a); Tahtalı DL (Taşdemir et al. 2010); EHEBSL (Yıldız et al. 2012); TTRR (Taş et al. 2012); Denizli mountain lakes (Yıldız \& Ustaoğlu 2016); Tigris R. (Zeybek et al. 2016); Aksu R. (Çapraz \& Arslan 2005); Tunca R. (Çamur-Elipek et al. 2006); Eğirdir L. (Arslan 2006);

Gediz Delta (Balık et al. 2004); Yuvarlak R. (Y1ldız et al. 2007b); Sapanca L. (Şahin \& Yıldız 2011); TTRR (Taş et al. 2012); Tunca R. (Çamur-Elipek et al. 2006);

Karamenderes S. (Odabaşı et al. 2017);

Buldan L. (Ustaoğlu et al. 2004);

Balıkdamı Wetland (Arslan et al. 2006);

Balıkdamı Wetland (Arslan et al. 2006);

Balıkdamı Wetland (Arslan et al. 2006);

Işıklı L. (Balık et al. 2000); Sazlıgöl L. (Balık et al. 2001); Gediz Delta (Balık et al. 2004); Eğrigöl L. (Yıldız et al. 2005); Lake District Region (Yıldız \& Balık 2005); Topçam DL (Yıldız \& Balık 2006); WBSL (Yıldız et al. 2008); Uludağ GL (Ustaoğlu et al. 2008); Balıkdamı Wetland (Arslan et al. 2006); Porsuk R. (Arslan \& İlhan 2010);

Gediz Delta (Balık et al. 2004);

Some Lagune L. (Yıldız et al. 2007c); Karasu R. (Zeybek et al. 2018); Gediz Delta (Balık et al. 2004); Eğrigöl L. (Yıldız et al. 2005); Lake District Region (Yıldız \& Balık 2005); Küçük Menderes R. (Balık et al. 2006a); TML (Yıldız et al. 2007a); Yuvarlak R. (Yıldız et al. 2007b); WBSL (Yıldız et al. 2008); Kemer DL (Yıldız et al. 2008); Uludağ GL (Ustaoğlu et al. 2008); Küçük Menderes CW (Yıldız et al. 2010a); Sapanca L. (Şahin \& Yıldız 2011); EHEBSL (Yıldız et al. 2012); Denizli mountain lakes (Yıldız \& Ustaoğlu 2016); Gölcük L. (Yıldız et al. 2015);

Eğrigöl L. (Yıldız et al. 2005); Lake District Region (Yıldız \& Balık 2005); Yuvarlak R. (Yildız et al. 2007b);

Hazar L. (Timm et al. 2013);

TTRR (Taş et al. 2012);

Işıklı L. (Balık et al. 2000); Gediz Delta (Balık et al. 2004); Eğrigöl L. (Yıldız et al. 2005); Küçük Menderes R. (Balık et al. 2006a); TML (Yıldız et al. 2007a); Küçük Menderes CW (Yıldız et al. 2010a); Tigris R. (Zeybek et al. 2016); Gölcük L. (Yıldı et al. 2015); Porsuk R. (Arslan \& İlhan 2010); Gala L. (Çamur-Elipek et al. 2010); Çatören and Kunduzlar DL (Arslan et al. 2014); Küçük Menderes R. (Arslan et al. 2016); 


\section{Phylum Annelida}

102 Limnodrilus hoffmeisteri Claparède, 1862

105
Limnodriloides pierantonii (Hrabě, 1971) 1871)

Limnodrilus hoffmeisteri f. parvus Southern, 1909
Locality? (Naidu 1965); Karagöl (Ustaoğlu 1980); Asi S. (Moubayed et al. 1987); Ankara S. (Kazancı \& Girgin 1998); Işıklı L. (Balık et al. 2000); Sazlıgöl L. (Balık et al. 2001); Gümüş S. (Öntürk \& Arslan 2003); Gediz Delta (Balık et al. 2004); Kuş L. (Balık et al. 2005); Eğrigöl L. (Yıldız et al. 2005); Lake District Region (Yıldız \& Balık 2005); Topçam DL (Yıldız \& Balık 2006); Yuvarlak R. (Yıldız et al. 2007b); WBSL (Yıldız et al. 2008); Kemer DL (Yıldı et al. 2008); Küçük Menderes CW (Yıldız et al. 2010a); Tahtalı DL (Taşdemir et al. 2010); EHEBSL (Yıldız et al. 2012); TTRR (Taş et al. 2012); Denizli mountain lakes (Yıldız \& Ustaoğlu 2016); Tigris R. (Zeybek et al. 2016); Karasu R. (Zeybek et al. 2018); Akgöl L. (Yıldız et al. 2009); İkizgöl (Yıldız et al. 2009); Aksu R. (Çapraz \& Arslan 2005); Kovada L. (Arslan \& Şahin 2006); Tunca R. (Çamur-Elipek et al. 2006); Eğirdir L. (Arslan 2006); Balıkdamı Wetland (Arslan et al. 2006); Musaözü DL (Arslan et al. 2007); Uluabat L. (Kökmen et al. 2007); Manyas L. (Arslan \& Ahıska 2007);

Çorlu R. (Taş et al. 2008); Menderes R. (Akbulut et al. 2009); Porsuk R. (Arslan \& İlhan 2010); Gala L. (Çamur-Elipek et al. 2010); Sazlıdere S. (Taş et al. 2011); Çatören and Kunduzlar DL (Arslan et al. 2014); Küçük Menderes R. (Arslan et al. 2016); Büyük Akgöl L. (Arslan et al. 2018); Euphrates R. (Aras \& Findık 2016); Ceyhan River Basin Lakes (Fındık \& Aras 2016); Çıldır L. (Arslan \& Mercan present study);

Eğrigöl L. (Yıldız et al. 2005); Lake District Region (Yıldız \& Balık 2005); Küçük Menderes R. (Balık et al. 2006a); Bozalan L. (Balık et al. 2006b); Some Lagune L. (Yıldız et al. 2007c); Sapanca L. (Şahin \& Yıldız 2011); Gölcük L. (Yıldız et al. 2015); Kovada L. (Arslan \& Şahin 2006);

Gediz Delta (Balık et al. 2004);

Işıklı L. (Balık et al. 2000); Gediz Delta (Balık et al. 2004); Kuş L. (Balık et al. 2005); Eğrigöl L. (Yıldız et al. 2005); Lake District Region (Yıldız \& Balık 2005); Küçük Menderes R.(Balık et al. 2006a); Yuvarlak R. (Yıldız et al. 2007b); Kemer DL (Yıldız et al. 2008); Küçük Menderes CW (Yıldız et al. 2010a); Denizli mountain lakes (Yıldız \& Ustaoğlu 2016); Tigris R. (Zeybek et al. 2016); Gölcük L. (Yıldız et al. 2015); Uluabat L. (Kökmen et al. 2007); Gala L. (ÇamurElipek et al. 2010); 


\section{Phylum Annelida}

106 Limnodrilus udekemianus Claparède, 1862

$107 \quad$ Limnodrilus sp.

108 Monopylephorus irroratus (Verrill, 1873)

109

$110 \quad$ Peipsidrilus sp.

111 Peloscolex arganoi Pop, 1974

112 Peloscolex boitanii Pop, 1974

113 Peloscolex cottarelli Pop, 1974

114 Peloscolex euxinicus Hrabě, 1966

115 Potamothrix alatus Finogenova, 1972

$116 \quad$ Potamothrix alatus hazaricus Timm \& Arslan, 2013

117 Potamothrix bavaricus (Oschmann, 1913)
Potamothrix bedoti (Piguet, 1913)
Ankara S. (Kazancı \& Girgin 1998); 1998; Işıklı L. (Balık et al. 2000); Gümüș S. (Öntürk \& Arslan 2003); Gediz Delta (Balık et al. 2004); Eğrigöl L. (Yıldız et al. 2005); Lake District Region (Yıldız \& Balık 2005); Küçük Menderes R. (Balık et al. 2006a); Topçam DL (Yıldız \& Balık 2006); TML (Yildız et al. 2007a); Yuvarlak R. (Yildız et al. 2007b); WBSL (Yıldız et al. 2008); Kemer DL (Y1ldız et al. 2008); Küçük Menderes CW (Yıldız et al. 2010a); Tahtalı DL (Taşdemir et al. 2010); TTRR (Taş et al. 2012); Denizli mountain lakes (Yıldız \& Ustaoğlu 2016); Gölcük L. (Yıldız et al. 2015); İkizgöl (Yıldız et al. 2009); Aksu R. (Çapraz \& Arslan 2005); Tunca R. (Çamur-Elipek et al. 2006); Eğirdir L. (Arslan 2006); Musaözü DL (Arslan et al. 2007); Manyas L. (Arslan \& Ahıska 2007); Çorlu R. (Taş et al. 2008); Menderes R. (Akbulut et al. 2009); Porsuk R. (Arslan \& İlhan 2010); Sazlıdere S. (Taş et al. 2011); Küçük Menderes R. (Arslan et al. 2016);

Tunca R. (Çamur-Elipek et al. 2006); Eğirdir L. (Arslan 2006); Menderes R. (Akbulut et al. 2009); Gala L. (Çamur-Elipek et al. 2010); Hazar L. (Şahin \& Baysal 1972);

Balıkdamı Wetland (Arslan et al. 2006); Çıldır L. (Arslan \& Mercan present study);

TTRR (Taş et al. 2012); Tunca R. (Çamur-Elipek et al. 2006);

Mersin (Pop 1974);

Mersin (Pop 1974);

Mersin (Pop 1974);

Gediz Delta (Balık et al. 2004);

Çıldır L. (Arslan \& Mercan present study);

Hazar L. (Timm et al. 2013);

Seyhan Dam Lake (Kırgız 1989); Gediz Delta (Balık et al. 2004); Eğrigöl L. (Yıldız et al. 2005); Lake District Region (Yıldız \& Balık 2005); Yuvarlak R. (Yıldız et al. 2007b); Some Lagune L. (Yıldız et al. 2007c); WBSL (Yıldız et al. 2008); Kemer DL (Yıldız et al. 2008); Uludağ GL (Ustaoğlu et al. 2008); Karasu R. (Zeybek et al. 2018); Gebekirse L. (Yıldız et al. 2009); Kovada L. (Arslan \& Şahin 2006); Eğirdir L. (Arslan 2006); Balıkdamı Wetland (Arslan et al. 2006); Musaözü DL (Arslan et al. 2007); Çatören and Kunduzlar DL (Arslan et al. 2014); Euphrates R. (Aras \& Fındık 2016); Çıldır L. (Arslan \& Mercan present study);

Kuș L. (Balık et al. 2005); Eğrigöl L. (Yıldız et al. 2005); Lake District Region (Yıldız \& Balık 2005); Küçük Menderes R. (Balık et al. 2006a); Topçam DL (Yıldız \& Balık 2006); Yuvarlak R. (Yıldız et al. 2007b); Some Lagune L. (Yıldiz et al. 2007c); WBSL (Y1ldiz et al. 2008); Kemer DL (Yıldız et al. 2008); Küçük Menderes CW (Yıldız et al. 2010a); Karasu R. (Zeybek et al. 2018); Karagöl L. (Topkara et al. 2018); Büyük Akgöl L. (Arslan et al. 2018); 


\section{Taxa}

Phylum Annelida

119 Potamothrix heuscheri (Bretscher, 1900)

Potamothrix hammoniensis

(Michaelsen, 1901)

121 \& Mrazek, 1902

\section{Literature data}

Lake District Region (Yıldız \& Balık 2005); Küçük Menderes R. (Balık et al. 2006a); Yuvarlak R. (Yildız et al. 2007b); Some Lagune L. (Yıldız et al. 2007c); WBSL (Yıldız et al. 2008); Küçük Menderes CW (Yıldız et al. 2010a); Karasu R. (Zeybek et al. 2018); Akgöl L. (Yıldız et al. 2009); Küçük Menderes R. (Arslan et al. 2016);

Seyhan Dam Lake (Kırgız 1989); Işıklı L. (Balık et al. 2000); Sazlıgöl L. (Balık et al. 2001); Gediz Delta (Balık et al. 2004); Kuș L. (Balık et al. 2005); Eğrigöl L. (Yıldız et al. 2005); Lake District Region (Yıldız \& Balık 2005); Küçük Menderes R. (Balık et al. 2006a); Topçam DL (Yıldız \& Balık 2006); TML (Yıldız et al. 2007a); Yuvarlak R. (Yıldız et al. 2007b); Some Lagune L. (Yıldiz et al. 2007c); WBSL (Yıldız et al. 2008); Kemer DL (Yıldız et al. 2008); Uludağ GL (Ustaoğlu et al. 2008); Küçük Menderes CW (Yıldız et al. 2010a); Sapanca L. (Şahin \& Yıldız 2011); TTRR (Taş et al. 2012); Denizli mountain lakes (Yıldız \& Ustaoğlu 2016); Karasu R. (Zeybek et al. 2018); Karagöl L. (Topkara et al. 2018); Gölcük L. (Yıldız et al. 2015); Gebekirse and Akgöl L. (Yıldız et al. 2009); Aksu R. (Çapraz \& Arslan 2005); Kovada L. (Arslan \& Şahin 2006); Tunca R. (Çamur-Elipek et al. 2006); Eğirdir L. (Arslan 2006); Balıkdamı Wetland (Arslan et al. 2006); Musaözü DL (Arslan et al. 2007); Uluabat L. (Kökmen et al. 2007); Manyas L. (Arslan \& Ahıska 2007); Menderes R. (Akbulut et al. 2009); Porsuk R. (Arslan \& İlhan 2010); Sazlıdere S. (Taş et al. 2011); Gölbaşı L. (Arslan et al. 2013); Çatören and Kunduzlar DL (Arslan et al. 2014); Küçük Menderes R. (Arslan et al. 2016); Büyük Akgöl L. (Arslan et al. 2018); Euphrates R. (Aras \& Fındık 2016); Ceyhan River Basin Lakes (Fındık \& Aras 2016); Çıldır L. (Arslan \& Mercan present study);

Potamothrix moldaviensis Vejdovský $\quad$ Eğrigöl L. (Yıldız et al. 2005);

Potamothrix vejdovskyi (Hrabě, 1941)
Potamothrix sp.
Psammoryctides albicola (Michaelsen,
1901)

Gediz Delta (Balık et al. 2004); Sapanca L. (Şahin \& Yıldız 2011); Eğirdir L. (Arslan 2006);

Işıklı L. (Balık et al. 2000); Sazlı̈öl L. (Balık et al. 2001); Gümüş S. (Öntürk \& Arslan 2003); Gediz Delta (Balık et al. 2004); Kuş L. (Balık et al. 2005); Lake District Region (Y1ldız \& Balık 2005); TML (Y1ldız et al. 2007a); Yuvarlak R. (Yıldız et al. 2007b); TTRR (Taş et al. 2012); Gölcük L. (Yıldız et al. 2015); Aksu R. (Çapraz \& Arslan 2005); Kovada L. (Arslan \& Şahin 2006); Tunca R. (Çamur-Elipek et al. 2006); Eğirdir L. (Arslan 2006); Balıkdamı Wetland (Arslan et al. 2006); Musaözü DL (Arslan et al. 2007); Uluabat L. (Kökmen et al. 2007); Manyas L. (Arslan \& Ahıska 2007); Menderes R. (Akbulut et al. 2009); Porsuk R. (Arslan \& İlhan 2010); Gölbaşı L. (Arslan et al. 2013); Çatören and Kunduzlar DL (Arslan et al. 2014); Küçük Menderes R. (Arslan et al. 2016); Euphrates R. (Aras \& Fındık 2016); Çıldır L. (Arslan \& Mercan present study);

Psammoryctides barbatus (Grube, $\quad$ Sazlı̈öl L. (Balık et al. 2001); Gediz Delta (Balık et al. 2004); Eğrigöl 1861)
L. (Yıldız et al. 2005); TML (Yıldız et al. 2007a); Sapanca L. (Şahin \& Yıldız 2011); Hazar L. (Timm et al. 2013); Çatören and Kunduzlar DL (Arslan et al. 2014); Ceyhan River Basin Lakes (Findık \& Aras 2016); 
126 Psammoryctides deserticola (Grimm, 1877)
Psammoryctides longicapillatus Martínez-Ansemil \& Giani, 1983

Psammoryctides moravicus (Hrabě, 1934)

\section{Psammoryctides sp.}

Rhyacodrilus coccineus (Vejdovský, 1876)

Spirosperma ferox (Eisen, 1879)

Spirosperma nikolskyi Lastočkin \& Sokolskaya, 1953

Spirosperma velutinus (Grube, 1879)

Stylodrilus parvus (Hrabe \& Černosvitov, 1927)

Stylodrilus heringianus Claparède, 1862

Tubifex acuticularis Martínez-Ansemil et Giani, 1983

Tubifex blanchardi Vejdovský, 1891

Tubifex costatus (Claparède, 1863)

Tubifex ignotus (Stolć, 1886)

Tubifex nerthus Michaelsen, 1908
Işıklı L. (Balık et al. 2000); Sazlıgöl L. (Balık et al. 2001); Gediz Delta (Balık et al. 2004); Kuş L. (Balık et al. 2005); Lake District Region (Yıldız \& Balık 2005); Küçük Menderes R. (Balık et al. 2006a); Topçam DL (Yıldız \& Balık 2006); TML (Yıldız et al. 2007a); Yuvarlak R. (Yild1z et al. 2007b); WBSL (Yıldız et al. 2008); Kemer DL (Yıldız et al. 2008); Küçük Menderes CW (Yıldız et al. 2010a); Sapanca L. (Şahin \& Yıldız 2011); TTRR (Taş et al. 2012); Denizli mountain lakes (Yıldız \& Ustaoğlu 2016); Tigris R. (Zeybek et al. 2016); Gölcük L. (Yıldız et al. 2015);

Euphrates (Moubayed et al. 1987);

Ankara S. (Kazancı \& Girgin 1998); Gediz Delta (Balık et al. 2004); TTRR (Taş et al. 2012); Tunca R. (Çamur-Elipek et al. 2006); Balıkdamı Wetland (Arslan et al. 2006);

Eğirdir L. (Arslan 2006);

Gümüş S. (Öntürk \& Arslan 2003); TTRR (Taş et al. 2012); Tunca R. (Çamur-Elipek et al. 2006); Balıkdamı Wetland (Arslan et al. 2006); Uluabat L. (Kökmen et al. 2007); Porsuk R. (Arslan \& İlhan 2010);

Ankara S. (Kazancı \& Girgin 1998); Işıklı L. (Balık et al. 2000); Sazlıgöl L. (Balık et al. 2001); Gediz Delta (Balık et al. 2004); Eğrigöl L. (Yıldız et al. 2005); Lake District Region (Yıldız \& Balık 2005); Sapanca L. (Şahin \& Yıldız 2011); EHEBSL (Yıldız et al. 2012);

Lake District Region (Yıldız \& Balık 2005); Denizli mountain lakes (Yıldız \& Ustaoğlu 2016);

Gediz Delta (Balık et al. 2004); Balıkdamı Wetland (Arslan et al. 2006); Çıldır L. (Arslan \& Mercan present study);

EBSL (Yildiz et al. 2010b); EHEBSL (Yildı et al. 2012); Balıkdamı Wetland (Arslan et al. 2006); Çıldır L. (Arslan \& Mercan present study);

EBSL (Y1ld1z et al. 2010b); EHEBSL (Y1ld1z et al. 2012);

Balıkdamı Wetland (Arslan et al. 2006); Çıldır L. (Arslan \& Mercan present study);

Denizli mountain lakes (Yıldız \& Ustaoğlu 2016);

Gediz Delta (Balık et al. 2004);

Sazlıgöl L. (Balık et al. 2001); Gediz Delta (Balık et al. 2004); Kuș L. (Balık et al. 2005); Lake District Region (Yıldız \& Balık 2005); Küçük Menderes R. (Balık et al. 2006a); TML (Y1ld1z et al. 2007a); Yuvarlak R. (Yıldız et al. 2007b); WBSL (Yıldız et al. 2008); Küçük Menderes CW (Yıldız et al. 2010a); Sapanca L. (Şahin \& Yıldız 2011); Balıkdamı Wetland (Arslan et al. 2006);

Sazlıgöl L. (Balık et al. 2001); Kuş L. (Balık et al. 2005); Eğrigöl L. (Yıldız et al. 2005); Lake District Region (Yıldız \& Balık 2005); Yuvarlak R. (Y1ldız et al. 2007b); WBSL (Y1ldız et al. 2008); Sapanca L. (Şahin \& Yıldız 2011); EHEBSL (Yıldız et al. 2012); TTRR (Taş et al. 2012); Denizli mountain lakes (Yıldız \& Ustaoğlu 2016); İkizgöl (Y1ld1z et al. 2009); 


\section{Taxa}

Literature data

Phylum Annelida

141 Tubifex newaensis (Michaelsen, 1903) Yuvarlak R. (Yildı et al. 2007b); Some Lagune L. (Yildiz et al. 2007c); Karasu R. (Zeybek et al. 2018);

142 Tubifex montanus Kowalewski, 1919

Eğrigöl L. (Yıldız et al. 2005); Lake District Region (Yıldız \& Balık 2005); Topçam DL (Yıldız \& Balık 2006); TML (Yıldız et al. 2007a); Yuvarlak R. (Yıldız et al. 2007b); EHEBSL (Yildız et al. 2012);

Gölcük L. (Geldiay \& Tareen 1972); Karagöl (Ustaoğlu 1980); Karasu S. (Çetinkaya et al. 1994); Ankara S. (Kazancı \& Girgin 1998); Işıklı L. (Balık et al. 2000); Sazlıgöl L. (Balık et al. 2001); Gümüş S. (Öntürk \& Arslan 2003); Gediz Delta (Balık et al. 2004); Kuș L. (Balık et al. 2005); Eğrigöl L. (Yıldız et al. 2005); Lake District Region (Yıldız \& Balık 2005); Küçük Menderes R. (Balık et al. 2006a); Bozalan L. (Balık et al. 2006b); Topçam DL (Yıldız \& Balık 2006); Yuvarlak R. (Yıldız et al. 2007b); Kemer DL (Yıldız et al. 2008); Uludağ GL (Ustaoğlu et al. 2008); Küçük Menderes CW (Yıldız et al. 2010a); Sapanca L. (Şahin \& Yıldız 2011); EHEBSL (Yıldız et al. 2012); TTRR (Taş et al. 2012); Denizli mountain lakes (Yıldız \& Ustaoğlu 2016); Tigris R. (Zeybek et al. 2016); Karagöl L. (Topkara et al. 2018); Gölcük L. (Yıldız et al. 2015); Gebekirse and Akgöl L. (Yıldız et al. 2009); İkizgöl (Yıldız et al. 2009); Aksu R. (Çapraz \& Arslan 2005); Kovada L. (Arslan \& Şahin 2006); Tunca R. (Çamur-Elipek et al. 2006); Eğirdir L. (Arslan 2006); Balıkdamı Wetland (Arslan et al. 2006); Musaözü DL (Arslan et al. 2007); Uluabat L. (Kökmen et al. 2007); Manyas L. (Arslan \& Ahiska 2007); Çorlu R. (Taş et al. 2008); Menderes R. (Akbulut et al. 2009); Porsuk R. (Arslan \& İlhan 2010); Gala L. (Çamur-Elipek et al. 2010); Sazlıdere S. (Taş et al. 2011); Çatören and Kunduzlar DL (Arslan et al. 2014); Büyük Akgöl L. (Arslan et al. 2018); Euphrates R. (Aras \& Fındık 2016); Ceyhan River Basin Lakes (Fındık \& Aras 2016); Çıldır L. (Arslan \& Mercan present study);

Locality? (Pop 1974); Upper Euphrates and Ankara S. (Moubayed et al. 1987); TML (Y1ldız et al. 2007a);

Eğrigöl L. (Yıldız et al. 2005); Lake District Region (Yıldız \& Balık 2005); Some Lagune L. (Y1ld1z et al. 2007); WBSL (Y1ld1z et al. 2008); Denizli mountain lakes (Yıldız \& Ustaoğlu 2016); Gebekirse L. (Yıldız et al. 2009);

146 Tubifex sp.

147 Tubifex spp.

$148 \quad$ Quistadrilus multisetosus (Smith, 1900)

Çıldır L. (Arslan \& Mercan present study);

Seyhan Dam Lake (Kırgız 1989); Enne S. (Tanatmış 1989); Akşehir L. (Sözen \& Yiğit 1999); Karacaören Dam Lake (Karaşahin \& Yıldırım 2000); EHEBSL (Yıldız et al. 2012); TTRR (Taş et al. 2012); Kovada L. (Arslan \& Şahin 2006); Tunca R. (Çamur-Elipek et al. 2006);

Işıklı L. (Balık et al. 2000); Sazlıgöl L. (Balık et al. 2001); Lake District Region (Yıldız \& Balık 2005); Denizli mountain lakes (Yıldız \& Ustaoğlu 2016);

$149 \quad$ Varichaetadrilus psammophilus (Loden, 1977)

Gediz Delta (Balık et al. 2004);

\section{Family Lumricidae}

$150 \quad$ Eisenella tetraedra (Savigny, 1826)

Adana (Omodeo 1956); Ankara S. (Kazancı \& Girgin 1998); Yuvarlak S. (Barlas et al. 2000); TTRR (Taş et al. 2012); Tunca R. (ÇamurElipek et al. 2006); Balıkdamı Wetland (Arslan et al. 2006); Porsuk R. (Arslan \& İlhan 2010); 
Phylum Annelida

151 Tatriella slovenica Hrabě, $1936 \quad$ Yuvarlak R. (Yıldız et al. 2007b);

Subphyl Annelida sbp Incertae sedis

um

\section{Order APHANONEURA}

Family Potamodrilidae

152 Potamodrilus fluviatilis (Lastočkin, $\quad$ Gediz S. (Balık et al. 1999); 1935)

Family Aeolosomatidae

153 Aeolosoma tenebrarum Vejdovský, Gediz S. (Balık et al. 1999); Gediz Delta (Balık et al. 2004); 1884

154 Aeolosoma headleyi Beddard, 1888 Tarsus (Pop 1974); Gediz S. (Balık et al. 1999);

155 Aeolosoma variegatum Vejdovský, Gediz S. (Balı et al. 1999); 1886

$156 \quad$ Aeolosoma leidyi Cragin, 1887

Gediz Delta (Balık et al. 2004);

157 Aeolosoma sp.

Gölcük L. (Geldiay \& Tareen 1972); Buldan L. (Ustaoğlu et al. 2004). 